\title{
A Review of the Traditional Uses, Medicinal Properties and Phytochemistry of Centaurea benedicta L.
}

\author{
Gagan Tiwana ${ }^{1,2}$, Jiahe Fua ${ }^{2}$, Lanping Lư ${ }^{2}$, Matthew J. Cheesman ${ }^{1,3}$, I.E.Cock ${ }^{2,4, *}$
}

Gagan Tiwana ${ }^{1,2}$, Jiahe Fua ${ }^{2}$, Lanping $\mathrm{Lu}^{2}$, Matthew J. Cheesman ${ }^{1,3}$, I.E.Cock ${ }^{2,4, *}$

'School of Pharmacy and Pharmacology, Gold Coast Campus, Griffith University, Parklands Drive, Southport, Queensland 4222, AUSTRALIA.

${ }^{2} S$ chool of Natural Sciences, Nathan Campus, Griffith University, Brisbane, AUSTRALIA. ${ }^{3}$ Menzies Health Institute Queensland, Quality Use of Medicines Network, Queensland 4222, AUSTRALIA.

${ }^{4}$ Environmental Futures Research Institute, Nathan Campus, Griffith University, Brisbane, AUSTRALIA.

\section{Correspondence}

\section{I.E.Cock}

School of Natural Sciences; Environmental

Futures Research Institute, Nathan

Campus, Griffith University, Brisbane,

AUSTRALIA

Phone no: +61 737357637

Fax: +61 737355282 ;

E-mail: I.Cock@griffith.edu.au

History

- Submission Date: 17-12-2020;

- Review completed: 22-02-2021;

- Accepted Date: 01-03-2021.

DOI : 10.5530/pj.2021.13.102

Article Available online

http://www.phcogj.com/v13/i3

Copyright

(C) 2021 Phcogj.Com. This is an openaccess article distributed under the terms of the Creative Commons Attribution 4.0 International license.

\begin{abstract}
Centaurea benedicta $\mathrm{L}$. is an annual herbaceous plant which belongs to the Asteraceae family. It is native to the Mediterranean region and western Asia and is commonly known as blessed thistle, holy thistle, St Benedict's thistle or spotted thistle. Traditionally, it has been used to treat bubonic plague and possesses diuretic, galactagogue, liver-strengthening and wound healing properties. Recent research studies have investigated its anticancer, antiinflammatory, antioxidant and other therapeutic properties. Several studies have also reported its antimicrobial activity against a range of bacterial pathogens. However, most of these studies were preliminary and only tested relatively high concentrations of the extracts. Additionally, most studies screened a limited number of pathogens. Cnicin is the main chemical compound present in $C$. benedicta and it has been widely investigated. However, few other compounds from this plant have been identified and/or investigated, and further phytochemical studies are warranted. Interestingly, pure cnicin has good anticancer activity, whilst the crude extracts lack cytotoxic properties. Phytochemical analyses of $C$. benedicta extracts reveal the presence of multiple flavonoids, tannins, terpenoids and lactones, although few specific phytochemicals within these phytochemical classes have been identified. A limited number of research studies have determined the toxicity profile of $C$. benedicta in order to evaluate its safety for human use. Substantially more detailed studies are required to rigorously investigate the therapeutic properties and phytochemistry of $C$. benedicta, which may ultimately lead to the development of new plant-based therapeutic medicines.
\end{abstract}

Key words: Asteraceae, Blessed thistle, St Benedict's thistle, Flavonoids, Terpenoids, Tannins.

\section{INTRODUCTION}

Humans have used traditional plant-based medicines to alleviate and treat diseases since ancient times. Fossil records indicate human use of plants as herbal medicines as long ago as 60,000 years. ${ }^{1}$ Plant-based medicine systems including Ayurveda, traditional Chinese Medicine (TCM), Kampo, traditional Korean medicine and Unani, have long been practiced by many cultures. Furthermore, numerous allopathic medicines such as atropine, colchicine, digoxin, quinine, and morphine are derived from Atropa belladonna L., Colchicum autumanle L., Digitalis purpurea L., Cinchona legeriana L. and Papaver somniferum L. respectively. These drugs are now commonly used globally for the management and treatment of multiple diseases. ${ }^{2}$ Compounds derived from traditional plant-based remedies possess significant biological activities and drug-like properties due to their unique chemical diversity and thus are a promising resource for the discovery and development of effective therapies.

In this review, we examine the traditional use, phytochemical composition and medicinal properties of Centaurea benedicta L (C. benedicta). This plant is commonly known as blessed thistle, St Benedict's thistle, holy thistle, or spotted thistle. It has been used traditionally for the management and treatment of multiple pathogenic and non- pathogenic conditions. It is an annual herbaceous plant of the family Asteraceae and is native to the Mediterranean region and western Asia, although it has now been widely naturalised globally. ${ }^{3}$ Centaurea benedicta has a particularly long history of medicinal usage, with the plant tops, leaves and stems used for a wide variety of therapeutic uses (Table 1). It is perhaps best known for its use in Europe in the Middle Ages for the treatment and prevention of the bubonic plague, which is caused by the bacterium Yersinia pestis. ${ }^{4,5}$ Presently, C. benedicta is commonly prepared and consumed as an infusion to stimulate appetite and to treat dyspepsia. The common name (blessed thistle) is believed to derive from its beneficial effects in the treatment of many different diseases, since it possesses diuretic, galactagogue, liver-strengthening and wound-healing properties, among others. ${ }^{5-8}$

Ethnobotanical knowledge of C. benedicta use has been handed down orally in many cultures and, as such, there is relatively little documentation of its traditional uses. Additionally, for most therapeutic uses there is little clinical evidence to support its efficacy. ${ }^{4,9}$ In contrast, the phytochemical composition of this species is relatively well reported. Furthermore, the therapeutic properties of many of the individual components have been examined and are relatively well known. This review describes the traditional uses of $C$. benedicta and summarises previous studies involving the screening of $C$. benedicta preparations

Cite this article: Tiwana G, Fua J, Lu L, Cheesman MJ, Cock IE. A Review of the Traditional Uses, Medicinal Properties and Phytochemistry of Centaurea benedicta L. Pharmacog J. 2021;13(3): 798-812. 
Table 1: Ethnopharmacological uses of C. benedicta.

\begin{tabular}{|c|c|c|}
\hline Traditional Uses & Preparation and Uses & References \\
\hline Abortifacient & Reported to be used as an abortifacient. Preparation and usage are not specified. & 18 \\
\hline Aids digestion & The bitterness of the cnicin component stimulates saliva flow and gastric acid secretion & $14,16,17$ \\
\hline Appetite booster & Powdered whole plant is consumed. & $14,16,18$ \\
\hline Boils, wound and skin ulcers & Decoctions are directly applied to treat bacterial skin diseases and skin sores. & $8,15,29$ \\
\hline Bubonic plague sores, & Decoctions were applied directly to treat bubonic plague sores. & $14,15,115$ \\
\hline Cardiovascular disease and hypertension & Preparation and treatment not specified. & 116 \\
\hline Contraceptive & $\begin{array}{l}\text { Leaves stems and flowers were used to prepare decoctions or infusions which are consumed } \\
\text { orally. }\end{array}$ & 14 \\
\hline Decrease flatulence & Decoctions or infusions prepared from the whole plant are consumed orally. & 14 \\
\hline Diabetes & $\begin{array}{l}\text { The plant is powdered, and an infusion is created using boiling water. This infusion is taken } \\
\text { orally before meals. }\end{array}$ & $116,117,118,119$ \\
\hline Diarrhoea & Decoctions and infusions have astringent properties and help relieve diarrhoea. & 14 \\
\hline Diuretic & Decoctions are consumed orally. The plant part used was not specified. & 14,18 \\
\hline Expectorant & Useful as an expectorant. Preparation and usage is not specified. & 14,18 \\
\hline Eye infections & $\begin{array}{l}\text { Prepared as a decoction and used as an eye wash to treat bacterial, fungal and viral eye } \\
\text { infections. }\end{array}$ & 11 \\
\hline Fungal skin disease & Decoctions are directly applied to treat ringworm and other fungal skin diseases. & $6,116,119$ \\
\hline Galactagogue & Powdered whole plant is consumed orally. & $4,14,18$ \\
\hline Gall stones & Decoctions or infusions prepared from the whole plant are consumed orally. & 14 \\
\hline Gastrointestinal issues & $\begin{array}{l}\text { Aids digestion, settles stomach upsets. A decoction of the whole plant is consumed as } \\
\text { needed. }\end{array}$ & $17,18,120$ \\
\hline Hypertension & Decoctions or infusions prepared from the whole plant are consumed orally. & 117 \\
\hline Inflammation & An infusion of the whole plant is taken to treat inflammation and arthritis. & $34,38,121$ \\
\hline Liver diseases & A decoction is consumed to prevent and treat liver disease. Diminishes jaundice. & $6,14,18,122$ \\
\hline Memory enhancer & Decoctions or infusions prepared from the whole plant are consumed orally. & 18,123 \\
\hline Menstrual pain & Decoctions or infusions prepared from the whole plant are consumed orally. & 14,18 \\
\hline Relieve symptoms of malaria & Decoctions are consumed orally. Plant part was not specified. Relieves fever. & $14,15,116,122$ \\
\hline Respiratory disease & $\begin{array}{l}\text { Used against multiple viruses including influenza. Used as an infusion or tincture. Useful in } \\
\text { clearing virus due to its expectorant properties. Relieves fever. }\end{array}$ & $14,18,124$ \\
\hline Urinary tract infections & Plant part, preparation and treatment not specified. & 116 \\
\hline
\end{tabular}

(and isolated compounds) against various diseases, while identifying gaps in the literature and proposing future studies. The phytochemistry and bioactivities of identified $C$. benedicta compounds have also been reviewed and where known, the mechanisms of action are reported.

\section{METHODS}

The medicinal properties, pharmacology and phytochemistry of $C$. benedicta are discussed. Peer-reviewed journal articles and books on herbal and traditional medicine were consulted. ${ }^{10,11}$ Google-Scholar, PubMed, Scopus and Science-Direct databases were used to source original scientific research papers. The following terms were used as filters and were searched both alone and as combinations: "blessed thistle", "St Benedict's thistle", "holy thistle", "spotted thistle", "traditional medicinal plant", "herbal medicine", "antibacterial", "inflammation", "anti-inflammatory", "antiviral", "bubonic plague", "Yersinia pestis". "appetite stimulant”, "dyspepsia", "fever" and "diarrhea".

\section{Eligibility criteria}

To meet the eligibility criteria for inclusion in this review, all published studies were required to be English language publications published prior to September 2020. Publications with the following criteria were excluded from this study:

- Studies where the species identity was in doubt. Where possible, the species names were confirmed using the Plant List website (http://www. theplantlist.org/). Where the taxonomic identity of the species could not be definitively verified, the study was omitted from this review.

- Studies describing the usage of milk thistle (Silybum marianus (L.) Gaertn.), Scotch thistle (Onopordum acanthium L.) and other thistles were excluded from the review.

\section{PLANT PROFILE AND TAXONOMY}

\section{Classification}

Centaurea benedicta L. is classified as kingdom plantae; clade tracheophytes; order Asterales; Family Asteraceae; genus Centaurea; species Centaurea benedicta $\mathrm{L}$.

\section{Synonyms}

Centaurea benedicta L. has also been known as Benedicta officinalis Bernh., Calcitrapa benedicta (L.) Sweet, Calcitrapa lanuginose Lam., Carbeni benedicta (L.) Arcang., Carbeni benedicta (L.) Adans, Cardosanctus officinalis Bubani, Carduus benedictus Auct. ex Steud., Carduus benedictus (L.) Garsault, Centaurea centriflora Friv. ex Gugler, Centaurea pseufobenedicta (Asch.) E.H.L.Krause, Cirsium horridum (Adams) Petr., Cnicus benedictus var. kotschyo Boiss., Cnicus bulgaricus Panov, Cnicus kotschyi Sch.Bip., Cnicus microcephalus Boiss., Cnicus pseudo-benedictus Asch. and Epitrachys microcephala K.Koch.

\section{Nomenclature and common names}

The Latin name $C$. benedicta is derived from the use by St. Benedict for its healing properties. ${ }^{12}$ Centaurea benedicta was well known in Europe in earlier times and is mentioned in William Shakespeare's play "Much Ado About Nothing" (written in 1598-1599 CE).

Common names in various traditional healing systems include:

Arabic: farasion, kanterion mubark, shok mubark, shok marimi, shok bari

English: blessed thistle, St. Benedict's thistle, holy thistle, spotted thistle French: chardon bénit 
German: benediktenkraut, bitterdistel

Portuguese: cardo-bento, cardo-santo

Russian: benedikt aptečnyj, knikus blagoslovennyj

Spanish: Cardo santo

Swedish: kardbenedikt

Chinese: cang ye hua, 祝福䔡

\section{Distribution}

Centaurea benedicta is native to the Mediterranean regions of Europe and is particularly prevalent in Portugal and Spain. ${ }^{13,14}$ It is also native to the northern African regions of Libya, Egypt, and the Middle Eastern regions of Iran, Iraq, Israel, Jordan, Lebanon and Syria, as well as Pakistan, Kazakhstan, Kyrgyzstan, Tajikistan, Turkmenistan, Uzbekistan and China. Centaurea benedicta has also been widely distributed and naturalised globally and is now common in most regions of the world.

\section{PHARMACOLOGICAL EFFECTS}

\section{Traditional uses}

Historically, there has been a myriad of uses for C. benedicta. Some of the more common uses are summarised in Table 1. The stems, leaves and flowers have been used to prepare "bitter" tonic drinks for oral consumption to treat bubonic plague sores and to relieve the symptoms of malaria, ${ }^{15}$ and to increase appetite and aid digestion. ${ }^{14,16,17}$ It is also used to relieve gastrointestinal distress and as an expectorant..$^{14,18}$ Centaurea benedicta is also used to treat liver diseases including jaundice. It is also useful for improving memory, as a galactagogue to increase milk production in nursing mothers, as a diuretic for increasing urine output, and for relieving menstrual pain. ${ }^{18}$ When applied to the skin, it is an effective treatment for boils, wounds, and skin ulcers. ${ }^{8,15}$

The traditional uses of $C$. benedicta originate from European healing systems, where the uses have been extensively verified and modified. However, despite the European origin of this plant, its widespread uses have attracted the attention of other healing systems including Ayurveda, Unani, Siddha and traditional Chinese systems of medicine. Indeed, it has now been included in these systems although it is generally considered by practitioners of these systems to be a "Western herbal galactagogue". 19,20

Despite its wide range of traditional applications, surprisingly few studies have rigorously examined the medicinal properties of $C$. benedicta and many therapeutic effects are yet to be verified. Studies have reported the antimicrobial, ${ }^{21-23}$ antiinflammatory ${ }^{24,25}$ and anticancer ${ }^{26-28}$ properties of $C$. benedicta preparations. However, many of these studies are preliminary and the plant preparations were screened against limited panels of pathogens/cell lines, or with limited and/or high doses of extracts. The MIC (minimum inhibitory concentration) and IC $_{50}$ values have often not been measured, making comparisons between studies impossible. Substantially more work is required to verify the medicinal properties of $C$. benedicta preparations, to quantify their efficacy and to determine the mechanisms of action. In contrast, the phytochemistry of $C$. benedicta has received substantially more consideration and many of the individual components have been screened for therapeutic properties. We will firstly review the traditional uses of crude $C$. benedicta preparations. The structure of the individual phytochemical constituents and their bioactivities will be summarised in a later section of this review.

\section{Antimicrobial activity}

Aqueous C. benedicta flower extracts have been reported to inhibit the growth of numerous bacterial pathogens including Salmonella typhimurium, Salmonella enteritidis, Shigella sonnei, Staphylococcus aureus, Streptococcus pyogenes, Proteus vulgaris, Enterococcus faecalis, Pseudomonas aeruginosa and Escherichia coli. ${ }^{29}$ Extracts were prepared using $40 \%$ ethanol and were diluted to $10 \%$ and $20 \%$ of the original concentration in aqueous solution for both the immature and mature $C$. benedicta flowers. Unfortunately, the concentration of the stock extracts was not specified in that study, so it is not possible to determine the concentrations tested in the bioassay. The diluted extracts exhibited good antimicrobial activity against both Gram-positive coccus species and Gram-negative bacillus microbes. Interestingly, both concentrations of diluted extract produced from mature flowers showed substantially greater antimicrobial activity than the extracts prepared using the immature flowers, highlighting the need to document such details in ethnopharmacological studies. Furthermore, the extracts produced from the mature flowers showed particularly promising antimicrobial activity against reference strains of Staphylococcus aureus, Streptococcus pyogenes and Escherichia coli. The extracts produced from both the mature and immature flowers also displayed significant antimicrobial activity against a clinical Bacillus proteus strain in agar disc diffusion assays, with zones of inhibition ranging from $22-32 \mathrm{~mm}$ in diameter. In future studies, MIC values need to be determined using more quantitative assay methods. Chromatographical, spectrophotometric and gravimetrical methods were used to characterize these extracts. Both contained an abundance of polyphenolic compounds, flavonoids, and tannins. Each of these classes of compounds have been shown to possess antibacterial activities and are likely to contribute to the growth inhibitory efficacies of the extracts.

Ethanolic extracts prepared from the roots of $C$. benedicta have been tested against Escherichia coli, Staphylococcus aureus and Micrococcus luteus. ${ }^{30}$ A zone of inhibition of $12 \mathrm{~mm}$ against $E$. coli was observed, despite the organism being resistant to ceftriaxone and gentamicin. However, the extracts were screened at very high concentrations $(75 \mathrm{mg} /$ $\mathrm{mL}$ ) and thus the reported bioactivity does not provide definitive proof of antibacterial activity of the extracts, nor does it allow for comparison with other studies. Furthermore, the lack of growth inhibition by the "positive antibiotic controls" also places the results in doubt. The concentrated extracts inhibited $S$. aureus growth with a $20 \mathrm{~mm}$ zone of inhibition, compared with $8 \mathrm{~mm}$ and $5 \mathrm{~mm}$ zones of inhibition reported for ceftriaxone and gentamicin, respectively. Qualitative phytochemical analysis of the extracts indicated the presence of flavonoids, alkaloids, carbohydrates, coumarins, lignin, terpenoids and phenolic compounds, but the authors did not conduct further analysis to identify the specific molecular compounds present within those phytochemical classes.

One of the most studied phytochemical constituents of Centaurea species is the sesquiterpene lactone compound, cnicin. One study screened cnicin against a panel of pathogenic Gram-positive and Gram-negative bacterial strains and reported significant antimicrobial activity, with MIC values ranging from $42-124 \mu \mathrm{g} / \mathrm{mL}$ against B. subtilis, S. epidermis, E. coli, K. pneumoniae, $P$. aeruginosa and S. aureus. ${ }^{31}$ Interestingly, cnicin also inhibits the growth of methicillin-resistant Staphylococcus aureus (MRSA), further highlighting its medicinal potential. Cnicin has been found to be a potent inhibitor of MurA, ${ }^{32}$ a bacterial enzyme that catalyses the first committed step in peptidoglycan synthesis, indicating this is a likely mechanism of action for the compound.

\section{Anticancer activity}

The anticancer properties of $C$. benedicta extracts remain largely unreported. In contrast, the anticancer properties of individual $C$ benedicta compounds have been relatively well documented, particularly for cnicin. Cnicin induces cell death in primary multiple myeloma cell lines, even in the presence of the tumour microenvironment and in the presence of survival cytokines. ${ }^{33}$ In addition, stromal and endothelial cell lines were unaffected by exposure to cnicin, although increases 
Table 2: Selected studies on the therapeutic properties of $C$. benedicta.

\begin{tabular}{|c|c|c|c|}
\hline Medicinal properties & Therapeutic effects & Efficacy & References \\
\hline \multirow{4}{*}{ Antimicrobial activity } & $\begin{array}{l}40 \% \text { ethanol extracts showed promising activity } \\
\text { against S. aureus, S. pyogenes, B. proteus and E. coli }\end{array}$ & $\begin{array}{l}\text { High concentrations of extracts }(10-20 \% \text {, or } 100-200 \\
\mathrm{mg} / \mathrm{mL}) \text { were screened in the agar diffusion assays. ZOIs } \\
\text { ranged from } 18-32 \mathrm{~mm}\end{array}$ & 29 \\
\hline & $\begin{array}{l}\text { Ethanolic extracts showed good activity against } E \text {. } \\
\text { coli, S. aureus }\end{array}$ & $\begin{array}{l}\text { Resuspension solvent not stated. High concentrations of } \\
\text { extracts }(25-75 \mathrm{mg} / \mathrm{mL}) \text { used in agar disc diffusion assays, } \\
\text { yielding } 10-15 \mathrm{~mm} \text { zones of inhibition }\end{array}$ & 30 \\
\hline & $\begin{array}{l}\text { Cnicin (a major component of Centaurea plant } \\
\text { species) inhibits B. subtilis, S. epidermidis, E. coli, K. } \\
\text { pneumoniae, P. aeruginosa and S. aureus growth }\end{array}$ & $\begin{array}{l}\text { Cnicin was purified from C. benedicta chloroform extracts } \\
\text { and tested in disc diffusion assays. Cnicin }(50 \mu \mathrm{g}) \text { produced } \\
\text { zones of inhibition of } 10-20 \mathrm{~mm}\end{array}$ & 31,32 \\
\hline & $\begin{array}{l}\text { Cnicin is a potent irreversible inhibitor of bacterial } \\
\text { enzyme MurA }\end{array}$ & $\begin{array}{l}\mathrm{IC}_{50} \text { of } 10-17 \mu \mathrm{M} \text { for cnicin towards } E \text {. coli or } P \text {. aeruginosa } \\
\text { MurA enzyme. }\end{array}$ & 32 \\
\hline \multirow{4}{*}{ Anticancer activity } & $\begin{array}{l}\text { Cnicin showed antitumor activity against multiple } \\
\text { myeloma cell lines }\end{array}$ & $\begin{array}{l}\text { Cnicin } \mathrm{IC}_{50} \text { values towards cell lines were } 3.4-14.7 \mu \mathrm{M} \text {, } \\
\text { with accompanying reductions in tumor sizes }\end{array}$ & 33 \\
\hline & $\begin{array}{l}\text { General cytotoxic effects of cnicin against breast } \\
\text { ductal carcinoma (BT-549) and kidney epithelial } \\
\text { (LLC-PK11) cells }\end{array}$ & $\begin{array}{l}\mathrm{IC}_{50} \text { values of } 18.5 \mu \mathrm{M} \text { against BT-549 cells and } 23.3 \mu \mathrm{M} \\
\text { against LLC-PK11 cells }\end{array}$ & 34 \\
\hline & $\begin{array}{l}\text { Cnicin is moderately active against HeLa, MCF- } 7 \text { and } \\
\text { A } 431 \text { cells }\end{array}$ & $\mathrm{IC}_{50}$ values for various cell lines between $16-35 \mu \mathrm{M}$ & 35 \\
\hline & $\begin{array}{l}\text { C. benedicta showed no cytotoxic effects against DU- } \\
145 \text { prostate cancer cells, MDA-MB-231 or MCF-7 } \\
\text { breast cancer cells }\end{array}$ & $\begin{array}{l}\text { Aqueous extracts }(50 \mu \mathrm{g} / \mathrm{ml}) \text { showed minimal reductions } \\
\text { in cell proliferation }\end{array}$ & 14,36 \\
\hline \multirow{2}{*}{$\begin{array}{l}\text { Anti-inflammatory } \\
\text { activity }\end{array}$} & $\begin{array}{l}\text { Cnicin showed significant inhibition of NF-kB in } \\
\text { PMA-induced SW1353 cells and iNOS activity in } \\
\text { lipopolysaccharide-induced RAW } 264.7 \text { cells }\end{array}$ & $\begin{array}{l}\text { Cnicin inhibits NF- } \mathrm{kB}\left(\mathrm{IC}_{50}=1.8 \mu \mathrm{M}\right) \text { and iNOS }\left(\mathrm{IC}_{50}=\right. \\
6.5 \mu \mathrm{M})\end{array}$ & 34 \\
\hline & $\begin{array}{l}\text { Cnicin inhibited inflammation in rat paw induced by } \\
\text { Macrovipera lebetina obstusa venom }\end{array}$ & $\begin{array}{l}2.5,5 \text { and } 10 \mathrm{mg} / \mathrm{kg} \text { doses of cnicin reduced inflammation } \\
\text { by up to } 28 \% \text { in experimental animals }\end{array}$ & 37 \\
\hline \multirow[b]{2}{*}{ Antioxidant } & $\begin{array}{l}\text { C. benedicta contains high flavonoid and phenolic } \\
\text { content (TPC), and ferric reducing antioxidant power } \\
\text { (FRAP) }\end{array}$ & $\begin{array}{l}\text { Methanolic extracts prepared from the consumable parts } \\
\text { of the plant (leaf and root) were resuspended in distilled } \\
\text { water. They inhibit xanthine oxidase }\left(\mathrm{IC}_{50}=18-20 \mu \mathrm{M}\right) \text { and } \\
\text { possess radical scavenging activity }\end{array}$ & 38 \\
\hline & $\begin{array}{l}\text { A nanofiltrate extract of } C \text {. benedicta contained } \\
\text { significant amounts of polyphenols }\end{array}$ & $\begin{array}{l}\text { Aerial segments of the plant extracted with } 50 \% \text { ethanol } \\
\text { and were concentrated by nanofiltration and tested } \\
\text { for antioxidant activity. } \mathrm{IC}_{50} \text { values of } 8.1 \mu \mathrm{g} / \mathrm{mL} \text { were } \\
\text { determined for scavenging activity and } 82 \mu \mathrm{g} / \mathrm{mL} \text { for } \\
\text { reducing power }\end{array}$ & 39 \\
\hline Antidiabetic activity & $\begin{array}{l}\text { Treatment with a saline suspension of C. benedicta } \\
\text { leaves extracted with methanol significantly } \\
\text { reduced plasma glucose levels in fasted normal and } \\
\text { streptozocin-induced diabetic rats }\end{array}$ & $\begin{array}{l}\text { Doses of } 100-400 \mathrm{mg} / \mathrm{kg} \text { reduced fasting plasma glucose } \\
\text { levels by } 84 \% \text { and streptozocin-induced diabetic plasma } \\
\text { glucose levels by } 45-66 \% \text {, compared to } 250 \mathrm{mg} / \mathrm{kg} \\
\text { chlorpropromide ( } 72 \%)\end{array}$ & 40 \\
\hline Antinociceptive activity & $\begin{array}{l}\text { A saline suspension of } C \text {. benedicta leaves extracted } \\
\text { with methanol significantly reduced the number of } \\
\text { writhes in albino rats compared with paracetamol } \\
\text { and indomethacin }\end{array}$ & $\begin{array}{l}\text { Doses of } 35-400 \mathrm{mg} / \mathrm{kg} \text { reduced the number of writhes by } \\
\text { up to } 75 \% \text {, compared to } 20 \mathrm{mg} / \mathrm{kg} \text { indomethacin and } 500 \\
\mathrm{mg} / \mathrm{kg} \text { paracetamol }\end{array}$ & 40 \\
\hline Wound healing effects & $\begin{array}{l}\text { A combination of } C \text {. benedicta root powder and } \\
\text { Vaseline induced potent wound healing activity } \\
\text { compared with Baneocin ointment }\end{array}$ & $\begin{array}{l}\text { Wound healing activity of almost } 99 \% \text { occurs with root } \\
\text { powder, compared with the reference ointment }(\sim 96 \%)\end{array}$ & 14,41 \\
\hline
\end{tabular}

in cell death occurred when cnicin was used in combination with standard therapeutic agents. The cytotoxic effects of cnicin have been reported to result from the increased production of reactive oxygen species, activation of caspases, and the downregulation of nuclear factor kappa-light-chain-enhancer of activated B cells (NF- $\kappa \mathrm{B})$. A microarray analysis study reported that cnicin treatment induced the downregulation of Pim-2 (a serine/threonine kinase), which functions in vitro as a survival kinase for myeloma cells. ${ }^{14}$ The downregulation results in the increased mortality of the myeloma cells. The antioxidant, cytotoxic and in vitro anti-inflammatory activities of cnicin have been studied $^{34}$ and reveal general cytotoxic effects against mammalian kidney fibroblasts (Vero) and kidney epithelial (LLC-PK11) cells. Additionally, in vitro anticancer properties of cnicin were demonstrated against four human solid tumor cell lines: breast ductal carcinoma (BT-549), ovary carcinoma (SK-OV-3), oral epidermal carcinoma (KB) and malignant melanoma (SK-MEL) cells. Mild cytotoxicity was observed for cnicin toward LLC-PK11 cells $\left(\mathrm{IC}_{50}=23 \mu \mathrm{M}\right)$, but no significant effects were noted against Vero cells. Antitumor effects were observed for cnicin towards SK-MEL and BT-549 cancer cell lines, with $\mathrm{IC}_{50}$ values of 14 and $18 \mu \mathrm{M}$, respectively.

When cnicin was tested against HeLa, MCF-7 and A431 carcinoma cells, moderate cytotoxic activities were evident against all cell lines. ${ }^{35}$ In contrast, aqueous $C$. benedicta extracts failed to induce cytotoxicity in vitro towards DU-145 prostate cancer cells, MDA-MB-231 and MCF-7 breast cancer cells, or against a non-malignant breast cancer cell line. ${ }^{14,36}$ This is an interesting finding, and it highlights differences between the effects of the purified components and the crude plant extracts on cancer cell lines.

\section{Anti-inflammatory activity and immunomodulation}

The anti-inflammatory activity and the effects of $C$. benedicta preparations on immunomodulation are yet to be examined thoroughly. However, cnicin has been found to inhibit NF- $\kappa B$ production in PMA-induced SW1353 cells with an $\mathrm{IC}_{50}$ of $1.8 \mu \mathrm{M}$, which compares 
favourably to the control anti-inflammatory drug parthenolide $\left(\mathrm{IC}_{50}\right.$ $6.4 \mu \mathrm{M}) .^{34}$ Cnicin also inhibits the pro-inflammatory mediator iNOS in LPS-induced macrophages but does not affect PMA-induced intracellular generation of ROS in HL-60 cells. ${ }^{34}$ In rats challenged with snake venom (which induces necrosis, pain and local oedemas), cnicin doses $(2.5-10 \mathrm{mg} / \mathrm{kg})$ reduced inflammation, indicating its effectiveness as an anti-inflammatory agent in vivo. ${ }^{37}$

\section{Antioxidant activity}

The leaves of $C$. benedicta contain approximately twice the content of phenolics and flavonoids as the roots. However, both parts of the plant possess considerable ferric reducing antioxidant power (FRAP) and 2,2 diphenyl-1-picryhydrazyl (DPPH) free radical scavenging activity, in addition to xanthine oxidase inhibition properties. ${ }^{38}$ Microfiltration and nanofiltration processes can be used to prepare extracts with substantially higher polyphenol content, DPPH scavenging activity and ferric reducing power. ${ }^{39}$

\section{Other therapeutic properties}

The antidiabetic and antinociceptive effects of a methanolic leaf extract of $C$. benedicta were investigated using an albino rat animal model. ${ }^{40}$ The animals were fasted overnight, and diabetes was induced with streptozotocin (STZ). Centaurea benedicta extracts (100-400 $\mathrm{mg} / \mathrm{kg}$, i.p.) significantly reduced blood glucose levels by $46-79 \%$ in the fasted normal rats and by $45-66 \%$ in STZ-induced diabetic rats. Furthermore, in oral glucose tolerance tests, administration of $C$. benedicta leaf methanolic extract reduced blood glucose concentration by $42-71 \%$. Antinociceptive activity was also investigated using the acetic acid writhing test. Leaf C. benedicta extract $(25-400 \mathrm{mg} / \mathrm{kg}$, i.p.) significantly reduced the number of writhes, with the percentage inhibition ranging from $68-74 \%$ compared with indomethacin $(20 \mathrm{mg} /$ $\mathrm{kg}$, i.p.) and paracetamol $(500 \mathrm{mg} / \mathrm{kg}$, i.p.) controls, which showed 69-75\% inhibition. Centaurea benedictus root powder also possesses wound healing properties in vivo, ${ }^{14,41}$ showing a $99 \%$ wound reduction over 2 weeks in a rat model. This is similar to levels obtained in rats treated with Baneocin ointment. Powdered C. benedicta was also used in combination with other medicinal plants to restore normal liver function. ${ }^{14}$ LIV-A is a product that consists of a combination of different herbs (including $C$. benedicta) and is used enhance digestion by increasing the secretion of bile.

\section{DOSAGE, TOXICITY, AND INTERACTIONS WITH OTHER MEDICINES}

\section{Dosage and toxicity}

Despite the long history of use of $C$. benedicta in traditional medicine, there is surprisingly little information on the dosage and toxicity of the plant. Generally, 4-6 g per day of cut herb or dried extract is believed to be adequate for most therapeutic purposes. When consumed as an infusion, it is recommended that $0.5-3 \mathrm{~g}$ of dried blessed thistle flowering tops be steeped in $150 \mathrm{~mL}$ of boiling water and consumed as a tea three times a day..$^{18}$ Alternatively, if an aqueous extract (prepared with equal amounts of dried plant material and water) or tincture (prepared with 1 part plant material to 5 parts alcohol) are used therapeutically, 1.5-2 $\mathrm{mL}$ or $7.5-10 \mathrm{~mL}$ respectively are recommended to be taken orally three times daily.

Limited data is available on the safety and toxicity of $C$. benedicta for human use and there are no definitive guidelines. Most commercially available supplements range from $300 \mathrm{mg}$ to $450 \mathrm{mg}$ per dose, and three doses per day is considered to be safe. Worsening side effects, including gastric irritation and vomiting, have been reported when the daily doses exceed $5 \mathrm{~g} .{ }^{42}$ In contrast to the whole plant and its preparations, toxicity data on some of the constituents is available. Cnicin, the major sesquiterpenoid component of $C$. benedicta, has an $\mathrm{LD}_{50}$ value of 1.6-3.2 $\mathrm{mmol} / \mathrm{kg}$ body weight in mice. ${ }^{14}$ Centaurea benedicta is not significantly mutagenic in the Ames test, with no mutagenicity observed in aqueous extracts at amounts up to $200 \mu \mathrm{L}$ per disc. ${ }^{43}$ However, mild mutagenic effects have been noted in alcoholic extracts at quantities of $400 \mu \mathrm{L}$ per disc. $^{44}$

\section{Adverse effects}

Centaurea benedicta is generally considered safe when used in moderation and administered as an infusion. However, it can cause gastrointestinal distress, nausea and vomiting if consumed in excess. ${ }^{45}$ Centaurea benedicta ingestion should be avoided in people with inflammatory bowel diseases, including Crohn's disease and ulcerative colitis, as it has been shown to increase the severity and duration of the symptoms. ${ }^{42,46}$

\section{Interactions with other medicines}

Several interactions have been reported between C. benedicta preparations and other therapies. The concurrent use of these therapies should therefore be avoided. Since the bitter phytoconstituents of $C$. benedicta (including cnicin) stimulate gastric acid production, they may reduce the effectiveness of antacids, rendering them ineffective while exacerbating gastric acidity and reflux. ${ }^{47}$ Therefore, the use of $C$. benedicta in individuals with heartburn and gastric reflux is discouraged. Similarly, C. benedicta has platelet activating factor (PAF) antagonist properties and can therefore prevent platelet aggregation, increasing the risk of bleeding. ${ }^{24}$ Its use should be avoided in individuals prescribed commercial anti-coagulants such as warfarin. ${ }^{48}$

C. benedicta constituents may also potentiate the activity of some other medicines. Indeed, the root and leaf extracts synergise the bactericidal activity of some antibiotics towards several bacterial pathogens. ${ }^{29,30}$ The use of these therapies concurrently would therefore be beneficial. Similarly, cnicin inhibits proliferation and metastasis of some tumour cells and potentiates the activity of some antitumour drugs. ${ }^{35}$ Whilst C. benedicta components are known to exert other therapeutic effects, their interaction with allopathic drugs is less well documented and substantially more work is required to understand these interactions. For example, cnicin has anti-inflammatory effects and may interact with NSAIDs. ${ }^{37,49}$ However, it is not known whether these interactions result in potentiation or in antagonism. Similarly, some C. benedicta lignans inhibit the replication of some human viruses ${ }^{50,51}$ and it is likely that they may interact with conventional antiviral agents. However, any such interactions have not yet been reported and this needs to be explored further.

\section{PHYTOCHEMISTRY}

The phytochemistry of $C$. benedicta preparations has been relatively well reported. The plant is relatively rich in sesquiterpenoid glycosides, particularly cnicin $(0.2-0.7 \%)$, polyacetylen and absinthin,,$^{52}$ as well as lower relative amounts of salonitenolide and artemisiifolin. These compounds are believed to be largely responsible for the bitter flavour of C. benedicta extracts. ${ }^{53} \mathrm{An}$ abundance of triterpenoids, including a-amyrenone, a-amyrin acetate, a-amyrine and multiflorenol acetate have also been reported. ${ }^{39}$ Additionally, the levels of tannins in $C$. benedicta extracts have been found to be as high as $8 \% .^{54}$ The lignans trachelogenin, nortracheloside and artigenin are also present in relative abundance in $C$. benedicta extracts, ${ }^{55}$ together with lower levels of flavonoids ${ }^{56}$ and essential oils. ${ }^{57}$ Additionally, C. benedicta has a high mineral content and is particularly high in potassium, manganese, magnesium and calcium. ${ }^{58}$ 


\section{Sesquiterpene lactones}

Sesquiterpene lactones (SLs) are a category of terpenoids that contain a lactone ring. They are particularly prevalent in plants of the family Asteraceae, including C. benedicta. Extracts produced from this species contain multiple sesquiterpene lactones including cnicin (0.2- $0.7 \%)$ (Figure 2a), polyacetylen (Figure $2 \mathrm{~b})^{41}$ and absinthin (Figure 2c)..$^{59}$ A recent study has also identified two new sesquiterpene lactone glycosides, melitensin $15-\mathrm{O}-\beta$-D-glucoside (Figure $2 \mathrm{~d}$ ) and $11 \beta, 13$ dihydrosalonitenolide $15-\mathrm{O}-\beta$-D-glucoside (Figure $2 \mathrm{e}$ ). ${ }^{52}$ Interestingly, dried $C$. benedicta plant material, volatile oil produced from the leaves, and isolated cnicin all have potent antibacterial activity against multiple pathogenic species (Newall et al., 1996). ${ }^{54}$ The sesquiterpene lactone structure of cnicin allows it to form covalent bonds with bacterial proteins, thereby disrupting the bacterial membrane structure and function. ${ }^{60}$ Furthermore, cnicin and its polyacetylene derivatives can inhibit quorum sensing in bacteria, thereby blocking biofilm formation and rendering the bacteria more sensitive to bactericidal treatments. ${ }^{61,62}$ They have been shown to affect cancer cells via multiple mechanisms, such as inducing cell cycle arrest, apoptosis, and angiogenesis, as well as enhancing reactive oxygen species-associated cancer cell death, inhibiting telomerase activity and preventing metastasis. ${ }^{63}$ Sesquiterpene lactones (particularly cnicin) also contribute to the bitter flavour of $C$. benedicta preparations..$^{53}$ These bitter agents induce increased salivary reflexes and gastric juice secretion, thereby stimulating appetite. ${ }^{16}$ Therefore, $C$. benedicta sesquiterpene lactones are also good appetite stimulants.

\section{Triterpenoids}

The basic terpenoid structure has been identified in almost 30,000 natural compounds and can be divided on the basis of the number of isoprene units into mono-, sesqui-, di-, sester-, tri, tetra-, and polyterpenes. ${ }^{64}$ It has been reported that oleanane, ursane, lupine and dammarane-euphane triterpenoid structures are the most important for biological applications. Indeed, some of these triterpenoids have anti-inflammatory, hepatoprotective, antimicrobial, antimycotic, analgesic, virostatic, immunomodulatory and tonic properties. ${ }^{64}$ Ulubelen and colleagues ${ }^{65}$ extracted different triterpene and steroidal compounds from the light petroleum and chloroform extracts of $C$. benedicta. The triterpenoid compounds a-amyrenone (Figure 3a), $a$-amyrine acetate (Figure $3 b$ ), $a$-amyrine (Figure $3 c$ ), multiflorenol acetate (Figure $3 \mathrm{~d}$ ), oleanolic acid, multiflorenol and sitosteryl-3 $\beta$-Dglucoside were identified by using UV, IR, NMR and mass spectral methods. Another study investigated the effects of four triterpenoids on a 12-O-tetradecanoylphorbol-13-acetate multiple dose model of skin chronic inflammation, and both erythrodiol and ursolic acid displayed substantial anti-inflammatory activity. ${ }^{66} \mathrm{~A}$ different study focused on the uses of the triterpenoids asiatic acid celastrol, oleanolic acid, ursolic acid and erythrodiol to protect the brain against neurodegenerative diseases including Parkinson's disease, Alzheimer disease, Huntington's disease, multiple sclerosis and amyotrophic lateral sclerosis. ${ }^{67}$ Furthermore, the hepatoprotective effects of 350 natural triterpenoids with diverse structures have been documented. ${ }^{68}$ Triterpenoid mechanisms of action have been suggested based on experimental data that has shown they downregulate cytokines to prevent inflammation, ${ }^{69}$ halt bacterial protein synthesis and reduce biofilm formation as antibacterial agents ${ }^{70,71}$ and reduce neuronal apoptosis to and improve cognitive impairment. ${ }^{72}$

\section{Lignans}

The lignans are a large group of polyphenols found in a wide variety of plant species. Interestingly, diets that are rich in plant lignans have been associated with decreased risks of cardiovascular disease. ${ }^{73-75}$ However, there is insufficient evidence to determine if lignans themselves are responsible for this cardioprotective activity, or if other plant components contribute. Furthermore, the intake of lignans reduces the incidence of hormone-related cancer ${ }^{47}$ although some studies have provided conflicting results. One study reported no association between breast cancer and total lignan intake in premenopausal women. ${ }^{76}$ However, the same group reported that dietary lignan intake in postmenopausal females resulted in a $17 \%$ decrease in the incidence of breast cancer in another study. ${ }^{77}$ More research is required to confirm the effects of high dietary intakes of lignans on hormone-related cancers and to determine their mechanism(s) of action. Several lignans have been reported in C. benedicta preparations in relative abundance. These include trachelogenin (Figure 4a), arctigenin (Figure 4b) and nortracheloside (Figure 4c) and these compounds may contribute to some of the therapeutic properties of this plant. One possible mechanism of action of trachelogenin in cancer cells is the induction of autophagy in carcinoma cells via light chain 3 (a microtubuleassociated protein) activation. ${ }^{78}$

\section{Flavonoids}

Flavonoids are polyphenolic compounds that are ubiquitous in plants and have important roles in traditional therapies against a wide variety of diseases. Indeed, multiple studies have reported antibacterial, antiviral, antiinflammatory, anticancer and anti-diarrhoeal effects for flavonoids. ${ }^{79,80}$ Interestingly, C. benedicta is rich in bioactive flavonoids including apigenin-7-O-glucoside (Figure 5a), luteolin (Figure 5b) and astragalin (Figure 5c). Bioflavonoids can prevent the oxidation of LDL cholesterol through their free radical scavenging activity and can inhibit endothelial cell growth and platelet aggregation. ${ }^{48,81,82}$ The antioxidant and free radical scavenging activities of flavonoids are due to their multiple hydroxyl groups and their location within the molecule. ${ }^{83}$ Examples of antibacterial mechanisms of action for the flavonoids include the attenuation of bacterial growth and pathogenicity by altering cytoplasmic membrane function and permeability, and inhibition of the bacterial DNA gyrase enzyme. . $^{84-86}$

\section{Tannins}

From a chemical point of view, it is difficult to define tannins, as the term is used to describe a wide variety of variable oligomers and polymers of gallic acid and/or ellagic acid. ${ }^{87}$ Tannins can be divided into four categories based on their structural characteristics: gallotannins, ellagitannins, complex hydrolysable tannins and condensed tannins. ${ }^{88-90}$ The structural characteristics of typical tannins within each of the classes are shown in Figure 6. Tannin and tannin-containing traditional medicines have a wide range of therapeutic uses. They are particularly important in Asian traditional medicine as astringents, to treat diarrhoea, as diuretics, and for the treatment of stomach and duodenal tumours. ${ }^{91}$ They are also used as anti-inflammatory, antiseptic, antioxidant and hemostatic therapies across multiple different cultures throughout the world..$^{92}$ Furthermore, epidemiological studies have reported decreased frequencies of chronic diseases in individuals whose diet comprises a high consumption of tannin rich plants. ${ }^{93}$ There are several mechanisms by which tannins can act as antibacterial agents, such as altering osmotic and $\mathrm{pH}$ regulation, interfering with metabolic pathways, and through the inhibition of the bacterial catalase enzyme. ${ }^{94,95}$

\section{Essential and volatile oils}

Essential and volatile components account for approximately $0.3 \%$ of the weight of $C$. benedicta plant material. ${ }^{21}$ Extracts from this plant are particularly rich in n-nonane, n-undecane, $\mathrm{n}$ - tridecane, citral (Figure 7a), dodeca-1,1l-dien-3,5,7,9-tetrain (polyyne), p-cymene (Figure 7b), fenchon (Figure 7c) and cinnamaldehyde (Figure 7d). ${ }^{21}$ Monoterpenes including citral have been reported to exert a wide variety of biological effects including antibacterial, antifungal, anti-inflammatory and antitumour activities. Citral is also cytotoxic towards some cancer 
cell lines. Indeed, both citral and 1,8-cineol can induce apoptosis in several human leukemia cell lines. ${ }^{96}$ Multiple other monoterpenoids also induce apoptosis and potentiate doxorubicin induced cytotoxicity in MCF-7 adenocarcinoma cell lines. ${ }^{97}$ The monoterpenes citral and pinene also induce apoptosis in melanoma cells. ${ }^{98}$ Similarly, multiple sesquiterpenoids have cytotoxic activities against cancer cells. ${ }^{99-103}$ Whilst we were unable to find reports of some of these terpenoids in $C$. benedicta extracts, this plant has not been thoroughly evaluated and it is possible that they may be reported in future studies.
Similarly, multiple mono- and sesquiterpenoids have been reported to suppress NF- $\mathrm{\kappa B}$ signaling (the major regulator of inflammatory diseases and cancer). ${ }^{104}$ In particular, citral, limonene ${ }^{105,106}$ and $\alpha$-pinene ${ }^{107}$ have been reported to inhibit NF- $\kappa B$ signalling pathways. These terpenoids also block inflammatory diseases and cancer by inhibiting p65 translocation into the nucleus in LPS-induced NF- $\kappa B$ signalling. ${ }^{107}$ Interestingly, many terpenoids including citral, p-cymene, fenchon and cinnamaldehyde also have good antibacterial activities. ${ }^{79}$ Thus, it is likely that $C$. benedicta terpenoids and volatile components contribute to the therapeutic properties of this species.

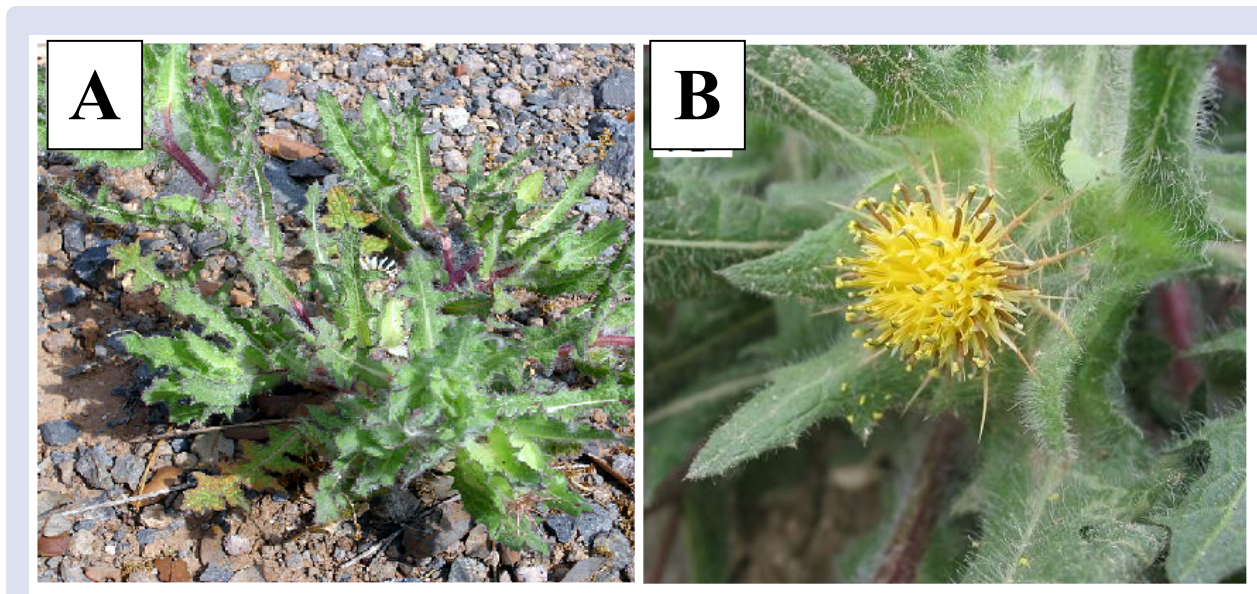

Figure 1: C. benedicta (a) whole plant and (b) a closer examination of the leaves and flower. Photographs are sourced from Wiki commons (https://commons.wikimedia.org/wiki/File:Cnicus_benedictus_flor.jpg; cited 27 November 2020) and are reproduced here with all relevant permissions.

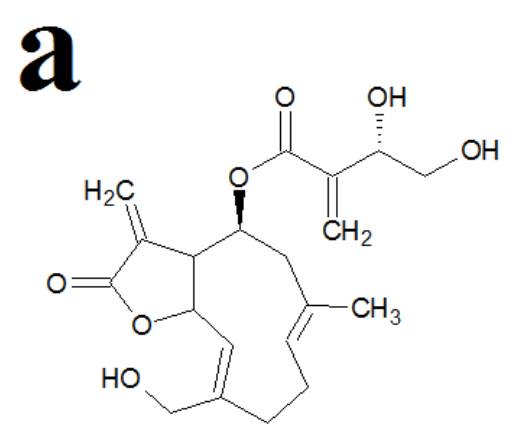<smiles>[101InH]</smiles><smiles>CC(C)=CC=CC=CC=CCC(C)C</smiles>

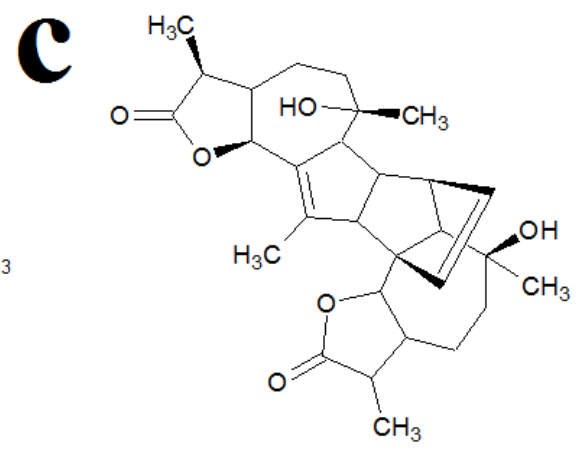

d<smiles>C=C[C@]1(C)C[C@H](O)[C@@H]2[C@@H](OC(=O)[C@@H]2C)[C@H]1C(=C)COC1OC(CO)C(O)C(O)C1O</smiles>

$\mathbf{e}$<smiles>CC(C)=CCC1C[C@H](O)[C@@H](C)C(=O)O[C@@H]1/C=C(\C)COC1OC(CO)C(O)C(O)C1O</smiles>

Figure 2: Chemical structures of selected sesquiterpene lactone molecules identified in C. benedicta: (a) cnicin, (b) polyacetylen, (c) absinthin, (d) melitensin 15-O- $\beta$-D-glucoside, (e) 11 1,13 -dihydrosalonitenolide 15-O- $\beta$-D-glucoside. 

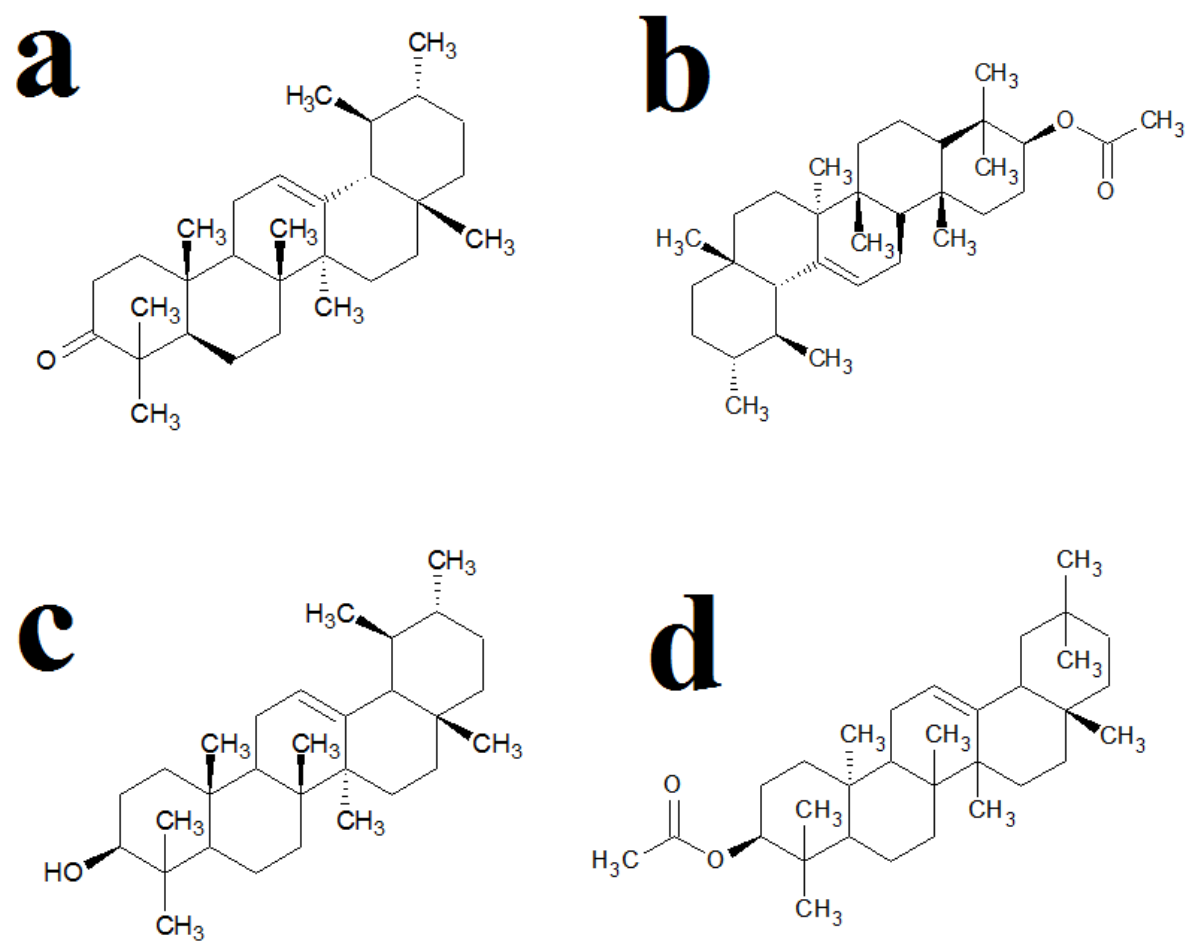

Figure 3: Chemical structures of selected triterpenoids molecules identified in C. benedicta: (a) a-amyrenone (b) a-amyrin acetate, (c) a-amyrine, (d) multiflorenol acetate.

\section{a}<smiles>COc1cc(C[C@@]2(O)C(=O)OC[C@H]2Cc2ccc(OC)c(OC)c2)ccc1O</smiles><smiles></smiles><smiles>COc1cc(C[C@@H]2COC(=O)[C@@H]2Cc2ccc(O)c(OC)c2)ccc1O</smiles>

\section{c}<smiles>COc1cc(C[C@@H]2COC(=O)[C@]2(O)Cc2ccc(O[C@@H]3O[C@H](CO)[C@@H](O)[C@H](O)[C@H]3O)c(OC)c2)ccc1O</smiles>

Figure 4: Chemical structures of selected lignan molecules identified in C. benedicta: (a) trachelogenin, (b) arctigenin, (c) nortracheloside. 
<smiles>C=C1C=C(c2ccc(O)cc2)Oc2cc(OC3O[C@H](CO)[C@@H](O)[C@H](O)[C@H]3O)cc(O)c21</smiles><smiles>O=c1c(OC2OC(CO)[C@H](O)[C@H](O)[C@H]2O)c(-c2ccc(O)cc2)oc2cc(O)cc(O)c12</smiles>

Figure 5: Chemical structures of selected flavonoids molecules identified in C. benedicta: (a) apigenin-7-Oglucoside, (b) luteolin, (c) astragalin.
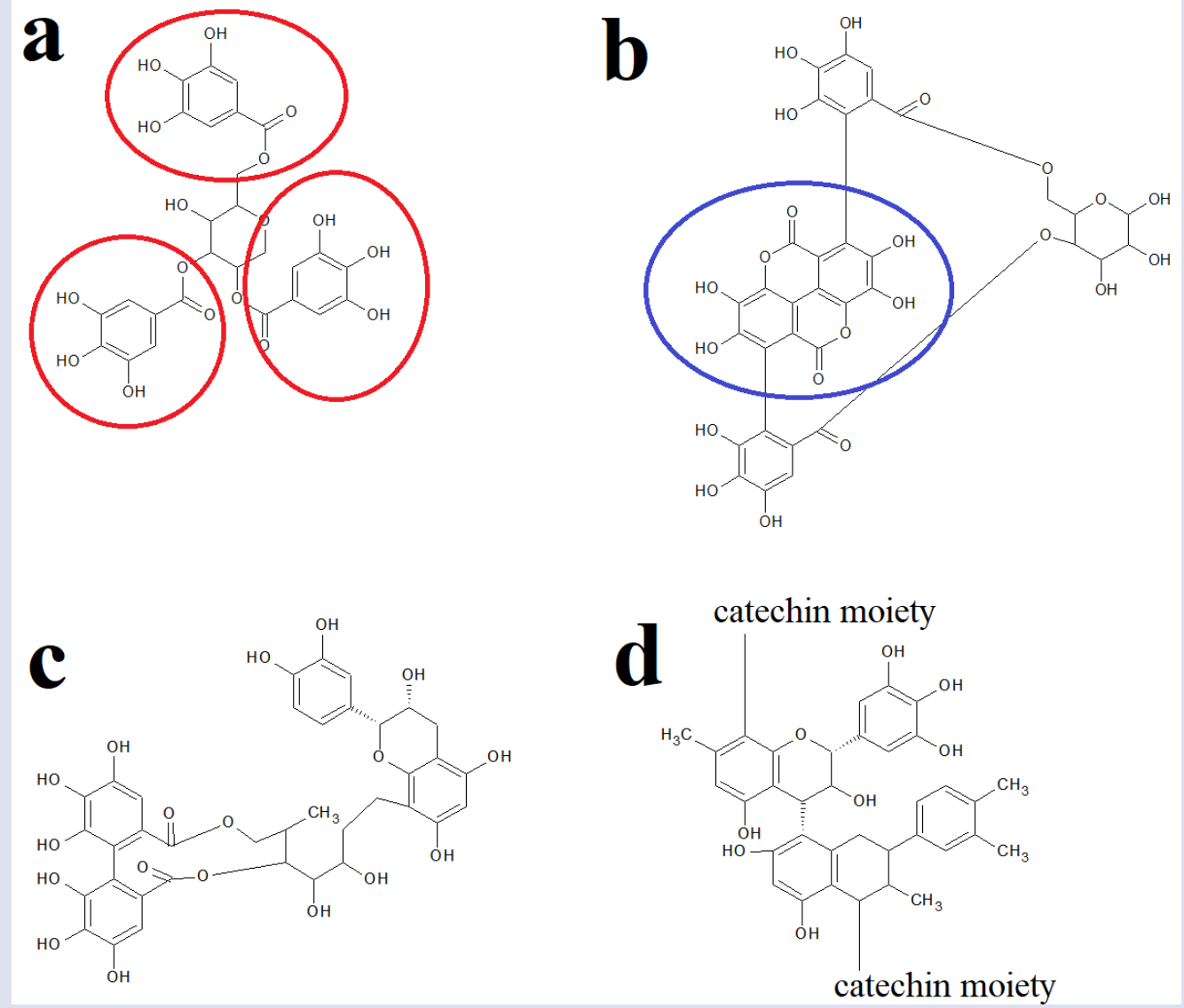

Figure 6: Classification of tannins: (a) gallototannin (gallic acid moieties indicated in red), (b) ellagitannin (ellagic acid moiety indicated in blue), (c) complex hydrolysable tannin, (d) condensed tannin. 


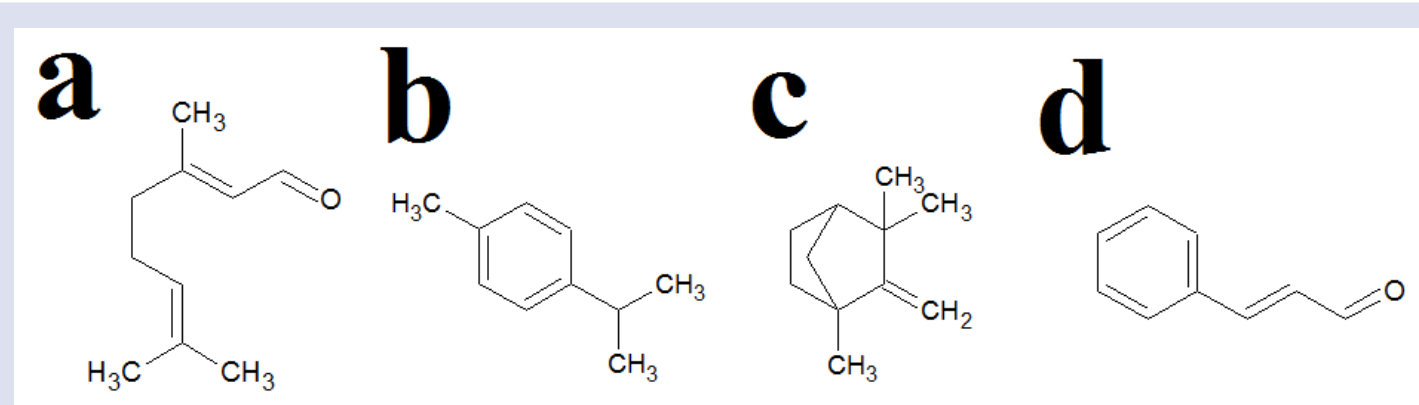

Figure 7: Chemical structures of selected essential and volatile oils molecules identified in C. benedicta: (a) citral, (b) p-cymene, (c) fenchon, (d) cinnamaldehyde.

\section{DISCUSSION}

The presence of chemically diverse compounds in plants has provided them with chemical defense systems against microbial infections and animal foraging. These phytochemicals can be utilised for novel natural drug discovery to develop semi-synthetic agents with high medicinal efficacy. Traditional medicines are currently attracting increased interest to treat health-related conditions due to their wide range of uses, availability, low cost, and perception of safety. Traditional medicine systems including Ayurveda, TCM, Unani are not only popular in their native countries, but are also gaining widespread acceptance and increased usage in Western medicinal systems. Recently, there has been an increase in awareness in plant-based medicines from regions including Africa, South America and Australia. A large number of drugs including atropine, caffeine, curcumin, colchicine, codeine and digoxin are used therapeutically and are derived from plant species. Furthermore, the anticancer drugs paclitaxel and camptothecin were discovered in a program sponsored by National Cancer Institute (NCI) in the United States and the Central Drug Research Institute (CDRI) in India, which screened almost 35,000 plants species from 1960-1981. ${ }^{108}$

Of the approximately 250,000 higher plant species (angiosperms and gymnosperms) that occur globally, only $6 \%$ have been investigated for any therapeutic activities. However, the advent of more efficient screening methods should increase the numbers of these studies, thus promoting the discovery of new drugs. Most pharmaceutical and biotechnology companies screen many thousands of plant-based compounds expediently via high throughput in vitro assay methodologies. ${ }^{109,110}$ The goals of using plant-based traditional medicines for drug discovery is to isolate bioactive chemical constituents with high activity and low toxicity. ${ }^{111}$ Alternatively, the whole plant may be used as a herbal medicine for holistic health promotion. Centaurea benedicta possesses notable phytochemicals including flavonoids, tannins, lignans, triterpenoids, sesquiterpene lactones, as well as essential and volatile oils, which may contribute to the antimicrobial, anticancer, antiinflammatory, antioxidant, immunomodulatory and other therapeutic properties of this species. ${ }^{8,29,38,55} \mathrm{Cnicin}$ is present in significant quantities in C. benedicta. ${ }^{12}$ Interestingly, cnicin has potent antibacterial activity against numerous Gram-positive and Gram-negative bacteria, including antibiotic resistant strains, and possesses cytotoxic properties against cancer cell lines. ${ }^{17,34,54}$ Numerous studies have reported additional properties such as antioxidant, anti-inflammatory, antidiabetic and antinociceptive activities. ${ }^{14,40,41}$ Together, these findings indicate that $C$. benedicta and its phytochemical constituents are a potential rich source of novel drug candidates.

Previous research studies have shown antimicrobial activities of blessed thistle using highly concentrated extracts (up to $70 \mathrm{mg} / \mathrm{mL}$ in some studies). Given the high concentrations/doses tested, it is not surprising that good activity was reported. However, screening such high doses may not indicate antibacterial activity, and would be classed as inactive in most other studies. Additionally, many of these studies reviewed herein tested only one or two different doses, and MIC values were not reported. These studies should be repeated to evaluate the efficacies of the $C$. benedicta extracts, allowing it to be benchmarked alongside other studies on the plant and other species so that appropriate comparisons can be made. It should also be noted that, in some of these studies, the extracts used in testing contained high concentrations of organic solvents such as methanol and ethanol, which would undoubtably complicate the analysis due to the inhibitory effects that these solvents exert on the cell lines being tested. Researchers should ensure that extracts are devoid of such solvents and are resuspended in aqueous solutions, and that they conduct control experiments with the resuspension solution to confirm that it does not contribute to the effects observed in the assays. As such, the activities of $C$. benedicta extracts in many of those studies are unreliable and should be repeated under these conditions. In any event, since research on crude extracts is already rather limited for this plant, this work would help increase our understanding of the properties of these preparations and thus provide a stronger platform for drug discovery efforts.

Although some studies have indicated antimicrobial properties of $C$. benedicta, relevant models of diseases should be implemented in each study to ensure that $C$. benedicta possesses activity against the causative agent(s) of that disease. For example, Staphylococcal and Streptococcal species cause skin disease, as do ringworm fungi, and thus collectively these pathogens should be tested for inhibition by $C$. benedicta to determine its potential applications in treating epidermal diseases. Urinary tract infections are caused by E. coli and Proteus mirabilis, and these species should be tested in the same way, as well as studies on pathogenic gastrointestinal bacteria (e.g. Salmonella spp. and Shigella spp.) which trigger diarrhoea. Any viral or parasitic organisms that cause these diseases should also be tested. Together, this would provide a more comprehensive analysis of the properties of $C$. benedicta in treating infectious diseases and thus provide a more expansive insight into the roles of the plant in human health.

Whilst some examination of $C$. benedicta antimicrobial, antiinflammatory, antioxidant and anticancer activities has been conducted, the plant is most commonly used as a galactagogue and yet there are no studies seeking to verify this therapeutic effect. Studies relevant to its galactagogue properties should therefore be undertaken. This is also true for studies to validate $C$. benedicta preparations for the treatment of specific types of cancers. To date, studies on the effects of $C$. benedicta using cancer cell lines has been quite broad, with testing being performed on a number of different cell lines, without focus on a specific cancer type (such as breast cancer, cervical cancer or prostate cancer). More focused approaches should be undertaken to determine the anticancer properties of $C$. benedicta on specific types of cancers, with a more extensive investigation that provides evidence of potential 
roles of the plant extracts or compounds isolated from the plant in treating certain cancers.

Phytochemistry studies reveal that C. benedicta contains a variety of flavonoids, coumarins, lignans, alkaloids, carbohydrates, terpenoids and polyphenols. Among these is the sesquiterpene lactone molecule cnicin, which has received considerable attention for its potential as a medicine. While some other compounds have been isolated and tested, it is interesting that investigation in this area has received limited attention. It is noteworthy that the activities of isolated compounds may be reduced or lost when purified, whilst they remain active in crude extracts, and act as potentiators of other compound(s) within extracts. Alternatively, they may have their activity potentiated by another molecule(s). Thus, it is possible that therapeutic properties can be missed by separating the various active phytochemicals. For example, Artemisia annua L. infusions (used in the treatment of malaria) have the same level of activity as a five-fold higher concentration of pure artemisinin when used as a monotherapy. ${ }^{113}$ A well-documented example of a synergistic relationship between two individual compounds in therapy is Augmentin", which contains both the antibacterial agent amoxicillin and a $\beta$-lactamase inhibitor, clavulanic acid. There are numerous other examples involving the use of plant-derived compounds in combination with currently available drugs to inhibit pathogenic microorganisms, including some antibiotic-resistant species. ${ }^{114}$ The use of different extracts and/or molecules isolated from $C$. benedicta, both alone and in combinations, may reveal similar synergistic relationships inhibiting the growth of pathogenic microbes. Similarly, this work could also be conducted with cancer cell lines using combinational assays (combining C. benedicta extracts and/or individual molecules) which could reveal far more powerful inhibition of cancer cell growth than using single compounds isolated from plant extracts.

To date, the vast majority of work conducted with C. benedicta has involved in vitro experimentation. It should be noted that as the extracts and isolated compounds are more rigorously characterized in terms of their activities and subsequent potential as medicinal agents, in vivo testing using whole animal studies will be required to determine both their efficacy and toxicity. A detailed analysis of their pharmacodynamic properties and their pharmacokinetic parameters should be performed alongside toxicity studies to more clearly define their mechanisms of action, distribution, efficacy and safety. Compound(s) or other preparations derived from $C$. benedicta that demonstrate favorable profiles may then be taken forward for early phase clinical trials in order to establish their usefulness in the treatment of human illnesses.

\section{CONCLUSIONS}

Ethnomedical knowledge is indispensable in the search for botanical resources for the development of new drugs. It has become widely apparent that plants which have been used traditionally for thousands of years are a promising source of potential new drugs and therapies. Centaurea benedicta is a promising plant species in this regard and evidence has emerged documenting its medicinal properties that support its traditional use. However, much work remains to uncover its hitherto undiscovered or uncharacterized properties. Research should be focused on the pathogens that are responsible for specific diseases, so that downstream therapies can be tailored to treat infections triggered by the relevant invading prokaryotic, viral and eukaryotic (fungi, parasites and cancer cells) organisms. Similarly, the likely complex interplay between $C$. benedicta and disease-triggering inflammatory agents or oxidant species should be more closely examined. In all cases, combinations of extracts, fractionated extract samples, and/ or individual molecules derived from the plant should be explored to identify possible instances where synergistic enhancements of efficacy occur. Moreover, drugs that are currently in use may be included in these combinatorial studies on C. benedicta to ascertain if improvements to current therapies are possible. An increased therapeutic effect elicited by the inclusion of $C$. benedicta would allow the doses of the conventional drug to be reduced, thus lowering drug toxicity risks. Furthermore, toxicity studies on $C$. benedicta and its components must also be conducted in parallel with the bioactivity experiments and the associated combination studies to provide a safety profile for the plant components involved. This should be conducted alongside detailed phytochemical analyses to identify the active molecular candidates involved, including those that may be potentiating the bioactivity of other plant components or conventional drugs. Together, this may lead to the development of effective drug therapies for the treatment of numerous ailment types, many of which are already purported to be ameliorated by the traditional uses of $C$. benedicta.

\section{ACKNOWLEDGEMENTS}

Financial support for this work was provided by the Environmental Futures Research Institute and the Quality Use of Medicines (QUM) Network, Griffith University, Australia.

\section{CONFLICTS OF INTEREST}

The authors declare no conflicts of interest.

\section{REFERENCES}

1. Yuan $\mathrm{H}, \mathrm{Ma} \mathrm{Q}, \mathrm{Ye} \mathrm{L}$, Piao $\mathrm{G}$. The traditional medicine and modern medicine from natural products. Molecules. 2016;21(5):559.

2. Kayne SB. Introduction to traditional medicine. In: Kayne SD, Editor Traditional Medicine: A Global Perspective. London: Pharmaceutical Press, p. 1-24; 2009.

3. Karnick CR. Pharmacopoeial Standards of Herbal Plants. New Dehli: Sri Satguru Publications, 1994.

4. Westfall RE. (2003). Galactagogue herbs: A qualitative study and review. Can J Midwifery Res Pract. 2003;2(2):22-27.

5. Sahan Y, Dulger D. (2013). Antioxidant properties and their bioaccessibility of Blessed Thistle under different processed treatments. FASEB J. 2013;27(1-supplement):1065.

6. Zeller W, De Gols M, Hausen BM. The sensitizing capacity of Compositae plants. Arch Dermatol Res. 277(1):28-35.

7. Nice, FJ. Common herbs and foods used as galactogogues. Infant Child Adolesc Nutr. 2011;3(3):129-132.

8. Mabona U, Van Vuuren SF. Southern African medicinal plants used to treat skin diseases. S Afr J Bot. 2013;87:175-193.

9. Abascal K, \& Yarnell E. Botanical galactagogues. Altern Complement Ther. 2008;14(6):288-294

10. Von Koenen E. Medicinal, poisonous and edible plants in Namibia. $4^{\text {th }}$ edition. Windhoek, Namibia: Klaus Hess Publishers, 2001.

11. Watt JM, Breyer-Brandwijk MG. The medicinal and poisonous plants of southern and eastern Africa. 2nd edition. Edinburgh, UK: E. \& S Livingstone Ltd., 1962.

12. Grieve, M. (2013). A modern herbal (Vol. 2). Courier Corporation.

13. Brummitt RK, Pando F, Hollis, S, Brummitt NA. World geographical scheme for recording plant distributions. Pittsburg: International Working Group on Taxonomic Databases for Plant Sciences (TDWG), 2001.

14. Al-Snafi AE. The constituents and pharmacology of Cnicus benedictusa review. Pharm Chem J. 2016;3(2):129-135.

15. Reichard K. Natural Standard: The Authority on Integrative Medicine. CQ Congress Collection (Vol. 8, No. 3), 2007.

16. Mclntyre M. British herbal compendium. In: Bradley PR, Editor. Vo 1: A handbook of scientific information on widely used plant drugs. (Companion to Vol 1 of the British Herbal Pharmacopoeia). UK: British Herbal Medicine Association, 1992.

17. Tešević $V$, Milosavljević $S$, Vajs $V$, Janaćković $P$, Đorđević I, Jadranin M, Vučković I. Quantitative analysis of sesquiterpene lactone cnicin in seven Centaurea species wild-growing in Serbia and Montenegro using ${ }^{1} \mathrm{H}-N M R$ spectroscopy. J Serbian Chem Soc. 2007;72(12):12751280 . 
18. Ulbricht C, Basch E, Dacey C, Dith S, Hammerness P, Hashmi S, Seamon E, Vora M Weissner W. An evidence-based systematic review of blessed thistle (Cnicus benedictus) by the Natural Standard Research Collaboration. J Diet Suppl. 2008;5(4):422.

19. Gabay MP. Galactogogues: Medications that induce lactation. J Hum Lact. 2002;18(3):274-9.

20. Mann BR, Zhang $\mathrm{H}$. Improvement in lactation with traditional Chinese medicine and western herbal medicine: A case study. J Chin Med. 2014;1(105):50-55.

21. Vanhaelen-Fastre R. Constitution and antibiotic properties of the essential oil of Cnicus benedictus (author's transl). Planta Med. 1973;24(2):165.

22. Eich E, Pertz $H$, Kaloga M, Schulz J, Fesen MR, Mazumder A, Pommier Y. (-)-Arctigenin as a lead structure for inhibitors of human immunodeficiency virus type-1 integrase. J Med Chem. 1996;39(1):86-95.

23. Hirano T, Gotoh M, Oka K. (1994). Natural flavonoids and lignans are potent cytostatic agents against human leukemic HL-60 cells. Life Sci. 1994;55(13):1061-1069.

24. Nose, M., Fujimoto, T., Takeda, T., Nishibe, S., \& Ogihara, Y. Structural transformation of lignan compounds in rat gastrointestinal tract. Planta Med. 1992;58(6):520-523.

25. Mascolo N, Autore G, Capasso F, Menghini A, Fasulo MP. Biological screening of Italian medicinal plants for anti-inflammatory activity. Phytother Res. 1987;1(1):28-31.

26. Barrero AF, Oltra JE, Morales $V$, Álvarez M, Rodríguez-García I. Biomimetic cyclization of cnicin to malacitanolide, a cytotoxic eudesmanolide from Centaurea malacitana. J Nat Prod. 1997;60(10):1034-1035.

27. Cobb E. Antineoplastic agent from Cnicus benedictus. Patent Brit. 1973:335:181.

28. Umehara K, Sugawa A, Kuroyanagi M, Ueno A, Taki T. Studies on differentiation-inducers from Arctium fructus. Chem Pharm Bull. 1993;41(10):1774-1779.

29. Szabó I, Pallag A, Blidar CF. (2009). The antimicrobial activity of the Cnicus benedictus L. extracts. Analele Univ. din Oradea, Fasc. Biol. 2009;16(1), 126-8.

30. Yasin YS, Hussian SM, Rahem SM. Antibacterial activity of ethanolic extract of leaves of the blessed thistle (Cnicus benedictus L.). AlMustansiriyah J Pharm Sci. 2018;17(1):9-9.

31. Bach SM, Fortuna MA, Attarian R, de Trimarco JT, Catalán CA, Av-Gay $Y$, Bach $\mathrm{H}$. Antibacterial and cytotoxic activities of the sesquiterpene lactones cnicin and onopordopicrin. Nat Prod Commun. 2011;6(2):1934578X1100600202.

32. Bachelier A, Mayer R, Klein CD. Sesquiterpene lactones are potent and irreversible inhibitors of the antibacterial target enzyme MurA. Bioorg Med Chem Lett. 2006;16(21):5605-5609.

33. Jöhrer K, Obkircher M, Neureiter D, Parteli J, Zelle-Rieser C, Maizner E, Kern J, Hermann M, Hamacher F, Merkel O, Wacht N. Antimyeloma activity of the sesquiterpene lactone cnicin: Impact on Pim-2 kinase as a novel therapeutic target. J Mol Med. 2012;90(6):681-693.

34. Erel SB, Karaalp C, Bedir E, Kaehlig H, Glasl S, Khan S, Krenn L. Secondary metabolites of Centaurea calolepis and evaluation of cnicin for anti-inflammatory, antioxidant, and cytotoxic activities. Pharm Biol. 2011;49(8):840-849

35. Forgo P, Zupkó I, Molnár J, Vasas A, Dombi G, Hohmann J. Bioactivityguided isolation of antiproliferative compounds from Centaurea jacea L. Fitoterapia. 2012;83(5):921-925.

36. Steenkamp V, Gouws MC. Cytotoxicity of six South African medicinal plant extracts used in the treatment of cancer. S Afr J Bot. 2006;72(4):630-633.

37. Demiroz T, Albayrak G, Nalbantsoy A, Gocmen B, Baykan S. Anti-inflammatory properties of Centaurea calolepis Boiss. and cnicin against Macrovipera lebetina obtusa (Dwigubsky, 1832) and Montivipera xanthina (Gray, 1849) venoms in rat. Toxicon. 2018;152:37-42.
38. Can Z, Baltaş N, Keskin S, Yıldız O, Kolaylı S. Properties of antioxidant and anti-inflammatory activity and phenolic profiles of Sevketi Bostan (Cnicus benedictus L.) cultivated in Aegean Region from Turkey. Turkish J. Agric. Food Sci. Technol. 2017;5(4):308-314.

39. Paun G, Neagu E, Moroeanu V, Albu C, Savin S, Lucian Radu G. Chemical and bioactivity evaluation of Eryngium planum and Cnicus benedictus polyphenolic-rich extracts. BioMed Res Int. 2019.

40. Bekale RB. Investigation of the antidiabetic activity of Cnicus benedictus L. in rats. PhD Thesis, School of Pharmacy, University of the Western Cape, South Africa, 2016.

41. Djamila C, Akym A, Faiza M, Chahinez B, Nacer-bey N. Anatomical, phytochemical and pharmacological studies of roots of Cnicus benedictus L. Int J Med Plants Res. 2013;2(2):204-208.

42. Mishra UK, Kanesh JS, Mandal AK, Das RK, Rayaguru K, Parija SC Potentials of herbal galactogogues in milk production in ruminants. The Ind Cow. 2006;2(9):44-52.

43. Schimmer O, Krüger A, Paulini H, Haefele F. An evaluation of 55 commercial plant extracts in the Ames mutagenicity test. Die Pharmazie. 1994;49(6):448-451.

44. Göggelmann W, Schimmer O. Mutagenicity testing of $\beta$-asarone and commercial calamus drugs with Salmonella typhimurium. Mutat Res Lett. 1983;121(3-4):191-194

45. Barrett NR. Spontaneous perforation of the oesophagus: Review of the literature and report of three new cases. Thorax. 1946;1(1):48.

46. Ulbricht C. Gastrointestinal Disorders: An integrative approach: A natural standard monograph. Altern Compliment Ther. 2010;16(1):3449.

47. Tamayo C, Richardson MA, Diamond S, Skoda I. The chemistry and biological activity of herbs used in Flor - Essence ${ }^{\mathrm{TM}}$ herbal tonic and Essiac. Phytother Res. 2000;14(1):1-14.

48. Cock IE. The medicinal properties and phytochemistry of plants of the genus Terminalia (Combretaceae). Inflammopharmacology. 2015;23(5):203-229.

49. Schneider G, Lachner I. Analysis and action of cnicin. Planta Med 1987;53(3):247-251.

50. Charlton JL. Antiviral activity of lignans. J Nat Prod. 1998;61(11):14471451.

51. Gnabre JN, Ito Y, MaY, Huang RC. Isolation of anti-HIV-1 lignans from Larrea tridentata by counter-current chromatography. J Chromatogr A. 1996;719(2):353-364.

52. Peng Y, Jian Y, Zulfiqar A, Li B, Zhang K, Long F, Peng C, Cai X, Khan IA, Wang W. Two new sesquiterpene lactone glycosides from Cnicus benedictus. Nat Prod Res. 2017;31(19):2211-2217.

53. Wagner H, Bladt S. Bitter Drugs. In: Plant drug analysis: A thin layer chromatography atlas. $2^{\text {nd }}$ edition. Heidelberg, Berlin: Springer, p. 7397, 1996.

54. Newall CA, Anderson L A, Phillipson JD. Herbal medicines: A guide for health-care professionals. $2^{\text {nd }}$ edition. London: Pharmaceutical Press. 1996.

55. Sólyomváry A, Tóth G, Kraszni M, Noszál B, Molnár-Perl I, Boldizsár I. Identification and quantification of lignans and sesquilignans in the fruits of Cnicus benedictus L.: Quantitative chromatographic and spectroscopic approaches. Microchem J. 2014;114:238-246.

56. Peng Y, Zhang K, Long F, Wang W, Ali Z, Khan IA. Sesquiterpenoids and flavonoids from Cnicus benedictus. Planta Med. 2016;82(5):PC7.

57. Kuhn MA, Winston D. Herbal Therapy and Supplements: A Scientific \& Traditional Approach. New York: Lippincott Williams and Wilkins. 2001.

58. Mumba NK, Csikai J, Petö G. Determination of $\mathrm{Mg}, \mathrm{Al}, \mathrm{Si}, \mathrm{Cl}$ and $\mathrm{K}$ in some medicinal plants by NAA and REA methods. Radiochem Radioanal Lett. 1982;52(6):373-381.

59. Kataria HC. Phytochemical investigation of medicinal plants Cinicus wallichii and Cnicus benedictus L. Asian J Chem. 1995;7(1):227.

60. Van Wyk, B. E., \& Wink, M. Medicinal plants of the world. CAB International. 2018. 
61. Hentzer M, Riedel K, RasmussenTB, Heydorn A, Andersen JB, Parsek MR, Rice SA, Eberl L, Molin S, Høiby N. Kjelleberg S. Inhibition of quorum sensing in Pseudomonas aeruginosa biofilm bacteria by a halogenated furanone compound. Microbiology. 2002;148(1):87-102.

62. Vanhaelen-Fastre R. Cnicus benedictus. Separation of antimicrobial constituents. Plantes Med Phytother. 1968;2:294-299.

63. Amorim MH, Gil da Costa RM, Lopes C, Bastos MM. Sesquiterpene lactones: Adverse health effects and toxicity mechanisms. Crit Rev Toxicol. 2013:43(7):559-79.

64. Dzubak P, Hajduch M, Vydra D, Hustova A, Kvasnica M, Biedermann D, Markova L, Urban M. Sarek J. Pharmacological activities of natural triterpenoids and their therapeutic implications. Nat Prod Rep. 2006;23(3):394-411.

65. Ulubelen A, Berkan T. Triterpenic and steroidal compounds of Cnicus benedictus. Planta Med. 1977;31(4):375-377.

66. Máñez S, Recio MC, Giner RM, Rı冈os JL. Effect of selected triterpenoids on chronic dermal inflammation. Eur J Pharmacol. 1997;334(1):103-105.

67. Ruszkowski P, Bobkiewicz-KozlowskaT. Natural triterpenoids and their derivatives with pharmacological activity against neurodegenerative disorders. Mini Rev Org Chem. 2014;11(3):307-315.

68. Xu F, Huang X, Wu H, Wang X. Beneficial health effects of lupenone triterpene: A review. Biomed Pharmacother. 2018;103:198-203.

69. Chen M, Oin Y, Ma H, Zheng $X$, Zhou R, Sun S, Huang $Y$, Duan O, Liu W, Wu P, Xu X. Downregulating NF-кB signaling pathway with triterpenoids for attenuating inflammation: in vitro and in vivo studies. Food Funct. 2019;10(8):5080-90

70. Chung PY. Novel targets of pentacyclic triterpenoids in Staphylococcus aureus: A systematic review. Phytomedicine. 2020;73:152933.

71. Dong S, Yang X, Zhao L, Zhang F, Hou Z, Xue P. Antibacterial activity and mechanism of action saponins from Chenopodium quinoa Willd. husks against foodborne pathogenic bacteria. Ind Crops Prod. 2020;149:112350.

72. Yu N, Huang Y, Jiang Y, Zou L, Liu X, Liu S, Chen F, Luo J, Zhu Y. Ganoderma lucidum Triterpenoids (GLTs) reduce neuronal apoptosis via inhibition of ROCK signal pathway in APP/PS1 transgenic Alzheimer's disease mice. Ox Med Cell Longev. 2020;1-11.

73. Vanharanta M, Voutilainen S, Rissanen TH, Adlercreutz H, Salonen JT. Risk of cardiovascular disease-related and all-cause death according to serum concentrations of enterolactone: Kuopio Ischaemic Heart Disease Risk Factor Study. Arch Intern Med. 2003;163(9):1099-1104.

74. Kilkkinen A, Erlund I, Virtanen MJ, Alfthan G, Ariniemi K, Virtamo J. Serum enterolactone concentration and the risk of coronary heart disease in a case-cohort study of Finnish male smokers. Am J Epidemiol. 2006;163(8):687-693.

75. Cunnane SC, Hamadeh MJ, Liede AC, Thompson LU, Wolever TM, Jenkins DJ. Nutritional attributes of traditional flaxseed in healthy young adults. Am J Clin Nutr. 1995;61(1):62-68.

76. Touillaud MS, Thiébaut AC, Niravong M, Boutron-Ruault MC, ClavelChapelon F. No association between dietary phytoestrogens and risk of premenopausal breast cancer in a French cohort study. Cancer Epidemiol Biomarkers Prev. 2006;15(12):2574-2576.

77. Touillaud MS, Thiébaut AC, Fournier A, Niravong M, Boutron-Ruault MC, Clavel-Chapelon F. Dietary lignan intake and postmenopausal breast cancer risk by estrogen and progesterone receptor status. J Natl Cancer Inst. 2007;99(6):475-486

78. Moura AF, Lima KS, Sousa TS, Marinho-Filho JD, Pessoa C, Silveira ER, Pessoa OD, Costa-Lotufo LV, Moraes MO, Araujo AJ. In vitro antitumor effect of a lignan isolated from Combretum fruticosum, trachelogenin, in HCT-116 human colon cancer cells. Toxicol in Vitro. 2018;47:129-36.

79. Cock IE. The phytochemistry and chemotherapeutic potential of Tasmannia lanceolata (Tasmanian pepper): A review. Pharmacogn Commun. 2013;3(4):13-25

80. Nijveldt RJ, Van Nood ELS, Van Hoorn DE, Boelens PG, Van Norren $K$, Van Leeuwen PA. Flavonoids: a review of probable mechanisms of action and potential applications. Am J Clin Nutr. 2001;74(4), 418-425.
81. Carluccio MA, Siculella L, Ancora MA, Massaro M, Scoditti E, Storelli C, Visioli F, Distante A, De Caterina R. Olive oil and red wine antioxidant polyphenols inhibit endothelial activation: antiatherogenic properties of Mediterranean diet phytochemicals. Arterioscler Thromb Vasc Biol. 2003;23(4):622-629.

82. Ruf JC. Wine and polyphenols related to platelet aggregation and atherothrombosis. Drugs Exp Clin Res. 1999;25(2-3):125-131.

83. Saxena M, Saxena J, Nema R, Singh D, Gupta A. Phytochemistry of medicinal plants. J Pharmacogn Phytochem. 2013;1(6).

84. Cushnie TT, Lamb AJ. Antimicrobial activity of flavonoids. Internat J Antimicrob Agents. 2005;26(5):343-356.

85. Xie Y, Yang W, Tang F, Chen X, Ren, L. Antibacterial activities of flavonoids: structure-activity relationship and mechanism. Curr Med Chem. 2015;22(1):132-149.

86. Farhadi F, Khameneh B, Iranshahi M, Iranshahy M. Antibacterial activity of flavonoids and their structure-activity relationship: An update review. Phytother Res. 2019;33(1):13-40.

87. Halliwell B, Gutteridge JMC. Role of free radicals and catalytic metal ions in human disease: An overview. Methods Enzymol. 1990;186:185.

88. Mangan JL. Nutritional effects of tannins in animal feeds. Nutr Res Rev. 1988;1(1):209-231.

89. Alokan JA, Aletor VA. Plant tannins - Their role in forage legume quality. $\quad$ http://www.internationalgrasslands.org/files/igc/ publications/1997/1-08-025.pdf. 1997.

90. Mole S, Waterman PG. Tannic acid and proteolytic enzymes: Enzyme inhibition or substrate deprivation?. Phytochemistry. 1986;26(1):99102.

91. De Bruyne T, Pieters L, Deelstra H, Vlietinck A. Condensed vegetable tannins: biodiversity in structure and biological activities. Biochem Syst Ecol. 1999;27(4):445-459.

92. Dolara P, Luceri C, De Filippo C, Femia AP, Giovannelli L, Caderni G, Cecchini C, Silvi S, Orpianesi C, Cresci A. Red wine polyphenols influence carcinogenesis, intestinal microflora, oxidative damage and gene expression profiles of colonic mucosa in F344 rats. Mutat ResFund Mol M. 2005;591(1-2):237-246.

93. Serrano J, Puupponen-Pimiä R, Dauer A, Aura AM, Saura-Calixto F Tannins: current knowledge of food sources, intake, bioavailability and biological effects. Mol Nutr Food Res. 2009;53(S2):S310-S329.

94. Carvalho RS, Carollo CA, de Magalhães JC, Palumbo JMC, Boaretto AG, e Sá IN, Ferraz AC, Lima WG, de Siqueira JM, Ferreira JMS. Antibacterial and antifungal activities of phenolic compound-enriched ethyl acetate fraction from Cochlospermum regium (mart. Et. Schr.) Pilger roots: Mechanisms of action and synergism with tannin and gallic acid. S Afr J Bot. 2018;114:181-187.

95. Liu M, Feng M, Yang K, Cao Y, Zhang J, Xu J, Hernández SH, Wei X, Fan M. Transcriptomic and metabolomic analyses reveal antibacterial mechanism of astringent persimmon tannin against Methicillinresistant Staphylococcus aureus isolated from pork. Food Chem. 2020;309:125692.

96. Moteki H, Hibasami H, Yamada $Y$, Katsuzaki H, Imai K, Komiya TA Specific induction of apoptosis by 1,8-cineole in two human leukemia cell lines, but not a in human stomach cancer cell line. Oncol Rep. 2002;9(4):757-760.

97. Gould MN. Cancer chemoprevention and therapy by monoterpenes. Environ Health Perspect. 1997;105(suppl 4):977-979.

98. Matsuo AL, Figueiredo CR, Arruda DC, Pereira FV, Scutti JAB, Massaoka MH, Travassos LR, Sartorelli P, Lago JH. $\alpha$-Pinene isolated from Schinus terebinthifolius Raddi (Anacardiaceae) induces apoptosis and confers antimetastatic protection in a melanoma model. Biochem Biophys Res Commun. 2011;411(2):449-454.

99. Park KR, Nam D, Yun HM, Lee SG, Jang HJ, Sethi G, Cho SK, Ahn KS. $\beta$-Caryophyllene oxide inhibits growth and induces apoptosis through the suppression of PI3K/AKT/mTOR/S6K1 pathways and ROS-mediated MAPKs activation. Cancer Lett. 2011;312(2):178-188. 
100. Tatman D, Mo H. Volatile isoprenoid constituents of fruits, vegetables and herbs cumulatively suppress the proliferation of murine B16 melanoma and human HL-60 leukemia cells. Cancer Lett. 2002;175(2):129-139.

101. Jin H, Kim HW, Xu CX, Kwon JT, Hwang SK, Lee ES, Chang SH, Park SJ, Noh MS, Woo MA, Yu KN. Effects of 7-hydroxy-3methoxycadalene on cell cycle, apoptosis and protein translation in A549 lung cancer cells. Biofactors. 2007;29(2-3):67-75.

102. Ding L, Pfoh R, Ruhl S, Qin S, Laatsch H. T-muurolol sesquiterpenes from the marine Streptomyces sp. M491 and revision of the configuration of previously reported amorphanes. J Nat Prod. 2009;72(1):99-101.

103. Ziaei A, Ramezani M, Wright L, Paetz C, Schneider B, Amirghofran Z. Identification of spathulenol in Salvia mirzayanii and the immunomodulatory effects. Phytother Res. 2011;25(4):557-562.

104. Salminen A, Lehtonen M, Suuronen T, Kaarniranta K, Huuskonen J. Terpenoids: natural inhibitors of NF- $\mathrm{KB}$ signaling with antiinflammatory and anticancer potential. Cell Mol Life Sci. 2008;65(19):2979-2999.

105. Lu XG, Zhan LB, Feng BA, Qu MY, Yu LH, Xie JH. Inhibition of growth and metastasis of human gastric cancer implanted in nude mice by d-limonene. World J Gastroenterol. 2004;10(14):2140.

106. Crowell PL. Prevention and therapy of cancer by dietary monoterpenes. J Nutr. 1999;129(3):775S-778S.

107. Zhou JY, Tang FD, Mao GG, Bian RL. Effect of alpha-pinene on nuclear translocation of NF-kappa B in THP-1 cells. Acta Pharmacol Sin. 2004;25(4):480.

108. Fabricant DS, Farnsworth NR. The value of plants used in traditional medicine for drug discovery. Environ Health Perspect. 2001;109(suppl 1):69-75.

109. Atanasov AG, Waltenberger B, Pferschy-Wenzig EM, Linder T, Wawrosch C, Uhrin P, Temml V, Wang L, Schwaiger S, Heiss EH, Rollinger JM. Discovery and resupply of pharmacologically active plant-derived natural products: A review. Biotechnol Adv. 2015;33(8):1582-1614

110. Beutler JA. Natural products as a foundation for drug discovery. Curr Protoc Pharmacol. 2019;86(1):e67.
111. Thomford NE, Senthebane DA, Rowe A, Munro D, Seele P, Maroyi A, Dzobo K. Natural products for drug discovery in the 21st century: innovations for novel drug discovery. Int J Mol Sci. 2008;19(6):1578.

112. Ghiasy-Oskoee M, AghaAlikhani M, Sefidkon F, Mokhtassi-Bidgoli A, Ayyari M. Blessed thistle agronomic and phytochemical response to nitrogen and plant density. Ind Crop Prod. 2018;122:566-573.

113. Cock IE, Selesho MI, Van Vuuren SF. A review of the traditional use of southern African medicinal plants for the treatment of malaria. J Ethnopharm. 2019;245:112176.

114. Cheesman MJ, llanko A, Blonk B, Cock IE. Developing new antimicrobial therapies: Are synergistic combinations of plant extracts/compounds with conventional antibiotics the solution? Pharmacogn Rev. 2017;11:57-72.

115. Fabbri CN. Treating medieval plague: The wonderful virtues of theriac. Early Sci Med. 2007;12(3):247-283.

116. Hulley IM, Van Wyk B-E. Quantitative medicinal ethnobotany of Kannaland (western Little Karoo, South Africa): Non-homogeneity amongst villages. S Afr J Bot. 2017;122:225-265.

117. Amel B. Traditional treatment of high blood pressure and diabetes in Souk Ahras District. J Pharmacognosy Phytother. 2013;5(1), 12-20.

118. Van Wyk B-E, Oudtshoorn B, Gericke N. Medicinal Plants of South Africa. South Africa: Briza Publishers, 1997.

119. Cock IE, Van Vuuren SF. A review of the traditional use of southern African plants for the treatment of fungal skin infections. J Ethnopharmacol. 2020;251:112539.

120. Ahmadimoghaddam D, Sadeghian R, Ranjbar A, Izadidastenaei Z, Mohammadi S. Antinociceptive activity of Cnicus benedictus L. leaf extract: A mechanistic evaluation. Res Pharm Sci. 2020;15(5):463.

121. Khumalo GP, Van Wyk B-E, Feng Y, Cock IE. A review of the traditional use of southern African medicinal plants for the treatment of inflammation and inflammatory pain. J Ethnopharmacol. In press.

122. Tagarelli G, Tagarelli A, Piro A. Folk medicine used to heal malaria in Calabria (southern Italy). J Ethnobiol Ethnomed. 2010;6(1):27.

123. Mautone M, De Martino L, De Feo V. Ethnobotanical research in Cava de'Tirreni area, Southern Italy. J Ethnobiol Ethnomed. 2019;15(1):50.

124. Van Wyk BE, Gorelik B. The history and ethnobotany of Cape herbal teas. S Afr J Bot. 2017:110:18-38. 


\section{GRAPHICAL ABSTRACT}

\section{A Review}

- Antioxidant
activity
- Antimicrobial
activity
- Anticancer
activity
- Anti-inflammatory
activity
- Immunomodulation

\section{C. benedictus}

Cnicin

\section{activity \\ Anticancer activity \\ Anti-inflammatory \\ Immunomodulation}
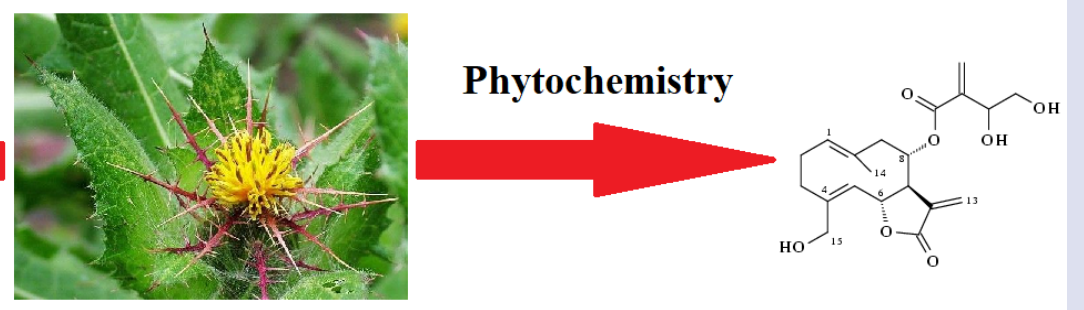

Therapeutic Properties
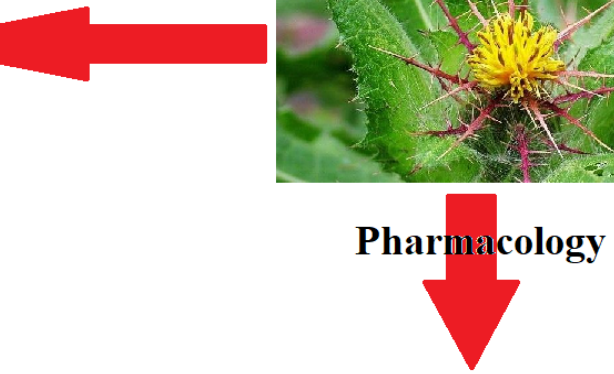

\section{-Dosage - Toxicity Adverse effects}

- Counter-indications

\section{ABOUT AUTHORS}

\section{- Mr Gagan Tiwana}

Mr Gagan Tiwana completed a Master of Pharmacy project on the medicinal properties of plants. He is seeking to begin a $\mathrm{PhD}$ in the area of traditional medicines in order to explore their potential in treating infectious diseases.

\section{- Jiahe Fua}

Jiahe Fua undertook an undergraduate project into the therapeutic properties of blessed thistle in our group and has recently graduated with degrees in science from Griffith University (Australia) and Nanjing University of Chinese Medicine (China).

\section{- Lanping Lu}

Lanping Lu undertook an undergraduate project into the therapeutic properties of blessed thistle in our group and has recently graduated with degrees in science from Griffith University (Australia) and Nanjing University of Chinese Medicine (China).

\section{- Dr Matthew Cheesman}

Dr Matthew Cheesman is a molecular biologist and biochemist who is interested in natural product discovery and the development of new antibacterial treatment therapies. His research focus is on plants as sources of new medicines for the treatment of multi-drug resistant infections.

\section{- Dr lan Cock}

Dr lan Cock leads a research team in the Environmental Futures Research Institute and the School of Natural Sciences at Griffith University, Australia. His research involves bioactivity and phytochemical studies into a variety of plant species of both Australian and international origin including Aloe vera, South Asian and South American tropical fruits, as well as Australia plants including Terminalia ferdinandiana (Kakadu plum), Tasmannia lanceolata, Scaevola spinescens, Pittosporum phylliraeoides, Australian Acacias, Syzygiums, Petalostigmas and Xanthorrhoea johnsonii (grass trees). This range of projects has resulted in more than 200 scientific publications in a variety of international peer reviewed journals. Dr Cock is also active in the administration and editorial aspects of scientific publication. He is currently on the editorial boards of 9 international peer reviewed journals. Of these, he is the editor in chief and foundation editor of the journal Pharmacognosy Communications.

Cite this article: Tiwana G, Fua J, Lu L, Cheesman MJ, Cock IE. A Review of the Traditional Uses, Medicinal Properties and Phytochemistry of Centaurea benedicta L. Pharmacog J. 2021;13(3): 798-812. 